$\underline{\text { Review }}$

\title{
Synthesis of Marine Natural Products in Brazil
}

\author{
Alphonse Kelecom \\ Departamento de Biologia Geral, Setor de Bio-Analítica, \\ Universidade Federal Fluminense, C.P. 100-436, 24001-970 Niterói - RJ, Brazil \\ Received: May 5, 1997

\begin{abstract}
So deadly is the force of this poison that it poisons not only those who took it in by mouth but also those who touched or looked at it, as Pliny reports, and if a pregnant woman sees it or even comes near it, especially if this happens to be a young woman,
\end{abstract} \\ she immediately feels pain in the belly and nausea, and then has an abortion.
}

[J Grevin 1568]

Descreve-se as sínteses de 23 produtos naturais marinhos, realizadas no Brasil ou por químicos brasileiros.

Syntheses of 23 marine natural products carried out in Brazil or by Brazilian chemists are comprehensively reviewed.

Keywords: diterpenes, sesquiterpenes, macroliste, nitrogenarest metabolites

\section{Introduction}

These are the words attributed to the greatest of the Latin naturalists, Gaius Plinius Secundus (known as Pliny the Elder A.D. 29-79), on describing the toxicity of the sea hare Aplysia in his encyclopedic work "Naturalis Historia"1. Later, it was reported that just touching Aplysia depilans would result in swelling of the body and depilation of hair ${ }^{2}$. Darwin also reported on an Aplysia which "exudes an acid secretion that causes a sharp stinging sensation" 3 . There are numerous references to the toxicity of mollusks; several date back to antiquity ${ }^{3}$. But there are not only unfavorable statements on mollusks. Tyrian purple is a good example. Phoenicians produced this dye from the snail Murex brandaris. It was prized so highly in ancient times that it was used as an emblem of royalty and in religious ceremonies. It had a high cost since 12,000 animals were necessary to produce only $1 \mathrm{~g}$ of dye. The dye production from mollusks is believed to go back at least to 1600 B.C., when the process was discovered by the Cre$\operatorname{tans}^{4}$. With the advent of the Dark Ages, dyeing with Tyrian purple became a lost art that was to be rediscovered only in Ireland in $1684^{5}$. Tyrian purple is no doubt the oldest commercial marine natural product known and its production perhaps the oldest record of the industrial use of a photochemical reaction, since it is obtained by light expo- sure of the colorless secretion of Murex gland. It was also the first marine metabolite whose structure, $\mathbf{1}$, was correctly deduced $^{6}$ and proven by synthesis of several dibromoindigo homologues ${ }^{7}$.

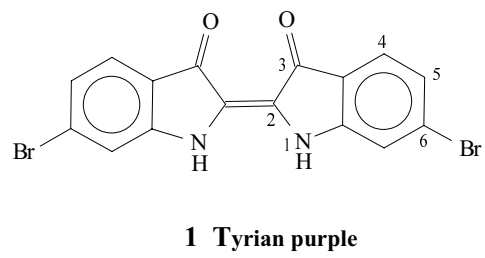

Hence, synthesis accompanied the early steps of marine natural products chemistry. However, the advancement of spectroscopic analysis, and principally of the NMR techniques, made possible the structural investigation and complete determination of complex molecules without the need of chemical methods. This has drastically limited our knowledge to almost nothing of the chemistry of marine natural products. The extreme originality of marine metabolites that often possess new skeletons, originated from completely new biosynthetic pathways, represented new challenges that triggered organic chemists. Thus, synthesis, that practically did not exist in the early eighties, is now giving "a powerful contribution to the understanding and development of marine organic chemistry" 8 . 
In Brazil, there has been a slow but continuous increase in the interest for marine natural products research along the past 20 years. In the first part of this review, studies related to isolation and structure determination were described $^{9}$. The second part of this review is dedicated to synthesis. The major published results of works done in Brazil will now be discussed in the following sections. The content of meeting abstracts, usually inaccessible to most foreign scientists, is included.

\section{Synthesis of Marine Natural Products}

The first Brazilian contributions in the field of organic synthesis were made by Rúveda and co-workers who synthesized some diterpenes from sponges and sea hares diterpenes, or their enantiomers, from the readily available copalic acid (2). Several sesquiterpenes were also the object of total syntheses. More recently, preliminary studies have appeared on the syntheses of one sesterterpene, one macrolide and nitrogen-containing metabolites.

\section{Diterpenes}

The first target was the tricyclic diterpene isoaplysin-20 (3), that had been isolated from the sea hare Aplysia kurodai, collected in Japan, and for which the stereochemistry at $\mathrm{C}-13$ had remained unclear ${ }^{10}$. The debromo homologue 4 was synthesized from copalic acid (2), following Scheme 1, in an eight-step sequence with an excellent overall yield $(49 \%)^{11}$. Thus, methyl isocopalate 6 was prepared by esterification of $\mathbf{2}$ into $\mathbf{5}$ and acid-catalyzed formation of the C-ring. Oxidation of the trisubstituted double bond with $\mathrm{OsO}_{4}$ furnished the expected $\beta$-oriented $\alpha$-glycol. The oxygen function at C-12 was then eliminated in the usual way, by oxidation to ketone $\mathbf{8}$, thioketal formation and hydrogenolysis on Raney-Ni into $\mathbf{1 0}$, which was finally reduced to debromo-isoaplysin-20 (4) ${ }^{11}$. This work fixed the rela-

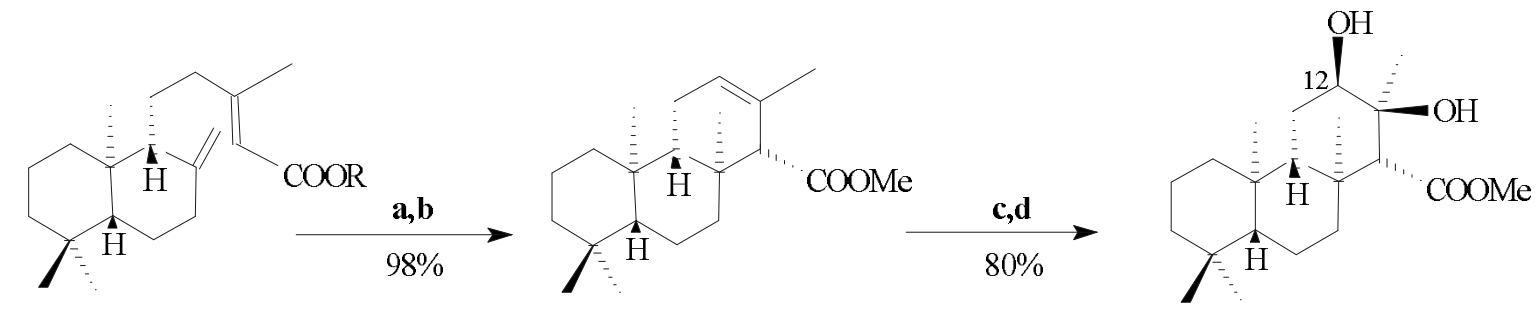

$$
\begin{aligned}
& 2 \mathrm{R}=\mathrm{H} \text { (copalic acid) } \\
& 5 \mathrm{R}=\mathrm{Me} \text { (methyl copalate) }
\end{aligned}
$$

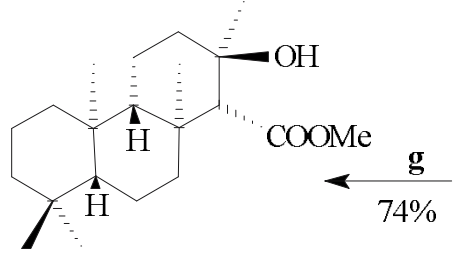

10<smiles>[Y][13C]([1H])=[13CH]</smiles>

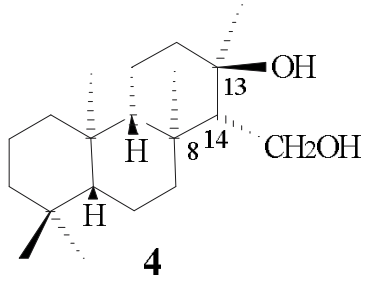

debromoisoaplysin-20

6 (methyl isocopalate)

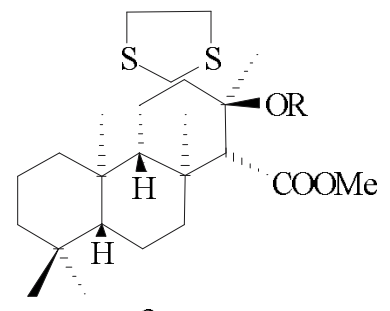

$9 \mathbf{a ~ R}=\mathrm{CH}_{2} \mathrm{SCH}_{3}$ b $\mathrm{R}=\mathrm{H}$<smiles>C[C@]1(O)CC[C@@H]2[C@@H]3CC[C@H](Br)[C@H](CO)[C@H]3CC[C@@H]21</smiles>

isoaplysin-20 (wrong structure)

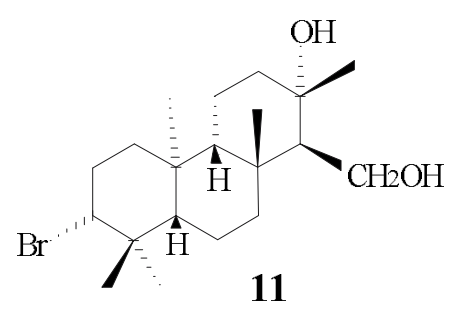

isoaplysin-20 (corrected structure)

Scheme 1. Synthesis of the supposed structure of debromoisoaplysin-20.

a. $\mathrm{CH}_{2} \mathrm{~N}_{2}, \mathrm{Et}_{2} \mathrm{O}$; b. $\mathrm{HCOOH} 98 \%$ aq; c. $\mathrm{OsO}_{4}$, dry Py , r.t., 65 h; d. $\mathrm{Na}_{2} \mathrm{~S}_{2} \mathrm{O}_{5}, \mathrm{Py}_{2} \mathrm{H}_{2} \mathrm{O}, 2,5$ h ; e. $\mathrm{DMSO} / \mathrm{Ac}_{2} \mathrm{O}$, r.t., $27 \mathrm{~h}$; f. $\mathrm{HSCH}_{2} \mathrm{CH}_{2} \mathrm{SH} /$ $\mathrm{BF}_{3} . \mathrm{Et}_{2} \mathrm{O}, \mathrm{AcOH}, 1 \mathrm{~h} ;$ g. Ni/Raney, EtOH reflux 8 h; h. LAH/THF, reflux 15 h - overall yield $49 \%$. 
tive stereochemistry at C-8, C-13 and C-14 as shown. However, some years later, the structure of isoaplysin-20 was corrected from 3 to $\mathbf{1 1}^{12}$.

The second target was $(+)$-isoagatholactone (12), the first spongiane diterpene that had been isolated from some samples of the Mediterranean sponge Spongia officinalis ${ }^{13}$. Remarkably, other samples of apparently the same sponge furnished C-21 and C-25 furanoterpenes and no isoagatholactone at all $^{13}$. This metabolite was successfully synthesized from (+)-manool (13) in an eight-step procedure whose key-step was the functionalization of the allylic methyl group of $\mathbf{1 6}$ through a sensitized photo-oxidation (Scheme 2) ${ }^{14}$. The desired allylic alcohol (18) was obtained in $17 \%$ yield. The overall yield of the synthesis cannot be calculated from published data, but is expected to be very low as the yield along the five final steps $\mathbf{1 6} \rightarrow 12$ was only $4 \%{ }^{14}$. Noteworthy are the three-step transformation of $(+)-$ manool (13) into ent-methyl isocopalate (15) shorter than the well-known sequence proposed by Fetizon and coworkers $^{15}$, the acid-catalyzed allylic rearrangement of $\mathbf{1 8}$ prior to lactonization and finally the two-step $\gamma$-lactone inversion $19 \rightarrow$ 12. Similarly, methyl isocopalate (6, i.e. ent-16) was transformed into ent-isoagatholactone (ent-12) through the sequence of reactions d-h depicted in Scheme 2 , in an overall yield of $8 \%$ (d, e: $16 \%$; f:88\%; g: $89 \%$ and h: $64 \%)^{16}$. An essentially identical total synthesis of $( \pm)-$ isoagatholactone was subsequently published ${ }^{17}$. It started from ent-copalic acid (the corresponding acid of 15) and differed only by the use of hematoporphyrin as photosentiziser, instead of methylene blue.

Three further diterpenes, ent-isocopal-12-en-15,16-dial (21), 14-iso-ent-isocopal-12-en-15,16-dial (22) and 15acetoxy-ent-isocopal-12-en-16-al (23) also isolated from Spongia officinalis ${ }^{18}$, were synthesized from racemic methyl isocopalate $( \pm 16)$ according to Scheme $3^{19}$. It should be noted that the low yield photo-oxidation reaction (Scheme 2 , step $\mathbf{d}$, yield $\approx 17 \%$ ) has been replaced by a two-step sequence of epoxidation and aluminium isopropoxide rearrangement to yield the desired allylic alcohol in $60 \%$ overall yield (Scheme 3, steps a and b). Interestingly, C-15 and C-20 terpenoids having two aldehyde groups in the same arrangement as exhibited in $\mathbf{2 2}$ usually taste very

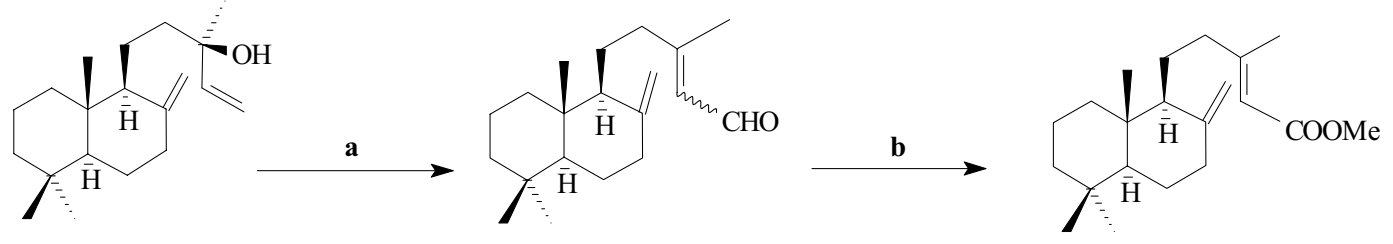

$13(+)-$ manool<smiles>C=C1[C@H](O)C[C@@H]2[C@@H](C)CCC[C@]2(C)[C@H]1C(C)=O</smiles>

$18(17 \%)$<smiles>[Y][AsH3]</smiles>

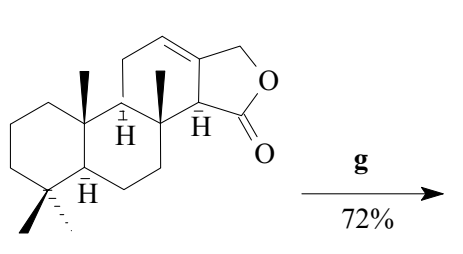

19
14 a E-aldehyde b Z-aldehyde<smiles>CC(=O)C1=C(C)[C@@H](O)C[C@H]2[C@@H]1CC[C@H]1[C@@H](C)CCC[C@]12C</smiles>
$17(33 \%)$

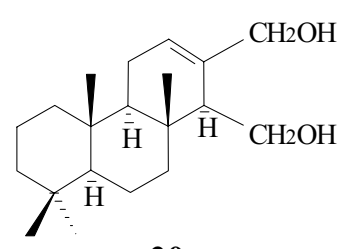

20
15 (ent-methyl copalate)<smiles>COC(=O)[C@H]1C(C)=CC[C@@H]2[C@@]3(C)CCCC(C)(C)[C@@H]3CC[C@]12C</smiles>

16

Scheme 2. Synthesis of (+)-isoagatholactone.

a. $\mathrm{PCC}$; b. $\mathrm{MnO}_{2}$ / $\mathrm{HCN}, \mathrm{MeOH}$ and $\mathrm{SiO}_{2}$ separation; c. $\mathrm{HCOOH}$, reflux; d. ${ }^{1} \mathrm{O}_{2}$, methylene blue, $\mathrm{EtOH} / \mathrm{AcOEt}(1: 1), 14$ h; e. $\left(\mathrm{CH}_{3} \mathrm{O}\right){ }_{3} \mathrm{P}$; f. $6 \mathrm{~N} \mathrm{H} \mathrm{H}_{2} \mathrm{SO} 4$ $\mathrm{H}_{2} \mathrm{O}$ - dioxane (1:13), $90{ }^{\circ} \mathrm{C}, 40 \mathrm{~min} ; \mathbf{g}$. $\mathrm{LAH} / \mathrm{Et}_{2} \mathrm{O} ; \mathbf{h} . \mathrm{MnO}_{2}, \mathrm{CH}_{2} \mathrm{Cl}_{2}$. 
hot to humans and are endowed of potent phagorepellent activities $^{20}$. Diterpene 22, however, is devoid of such biological properties ${ }^{18}$.

Ambergris is a concretion found in the gut of the sperm whales Physeter spp. It has been used for centuries because of its unique fragrance and fixative properties ${ }^{21,22}$, but is now commercially abolished thanks to the Marine Mammalians Protection Act. Copalic acid (2) has been used as a chiral synthon for the obtention of several compounds related to the constituents of ambergris ${ }^{23,24}$. Scheme 4 depicts the syntheses of ent-8-epi-ambraketal (30), ent-ambrox (31) and related oxides $\mathbf{3 2}$ and $\mathbf{3 3}^{23-25}$. The key-step in the synthesis of ent-ambrox (31) is a smooth Baeyer-Villiger oxidation of the unstable epoxy-ketone 29 into $34^{24}$. Spontaneous rearrangement of $\mathbf{2 9}$ into $\mathbf{3 0}$ has also been observed $^{23}$; this reaction is assumed to be catalysed by traces of acid present in the reaction medium ${ }^{25}$.

Finally, preliminary studies toward the synthesis of ambliol-B (38), from the Californian sponge Dysidea amblia $^{26,27}$ have resulted in the inter-conversion of hardwickiic acid (39) into dehydroambliol-B (40) (Scheme 5) ${ }^{28}$. The key intermediate 44 was prepared from alcohol 42 or its acetate $\mathbf{4 3}$, through a reaction with nickel boride generated in situ. It should be emphasized that dehydration of ambliol-B (38) with phosphorous oxychloride in pyridine gave trisubstituted olefin $\mathbf{4 5}$ while acid-catalyzed dehydration produced tetrasubstituted olefin $\mathbf{4 0}^{26,27}$. The yields of the reactions have not been reported ${ }^{28}$. Further work is underway to achieve the synthesis of ambliol-B. Recently, a total synthesis of racemic ambliol-B has been publish$\mathrm{ed}^{29}$. As reported above for Spongia officinalis, chemical analyses of individual animals have revealed, here again,

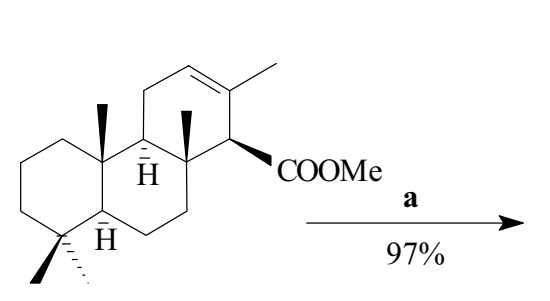

(+/-) 16

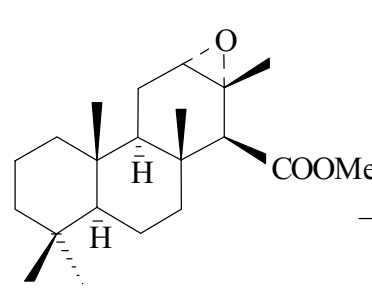

24

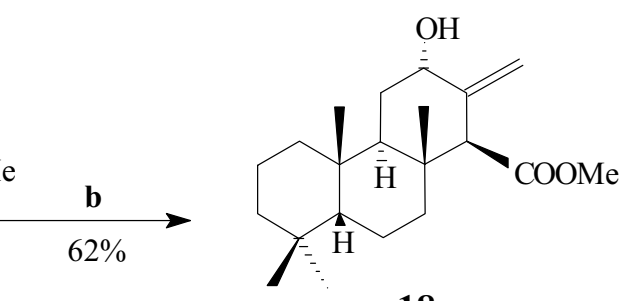

18<smiles>C[C@H]1CCC[C@@]2(C)[C@H]1CC[C@]1(C)[C@@H](C)C(C=O)=CC[C@H]21</smiles>

21
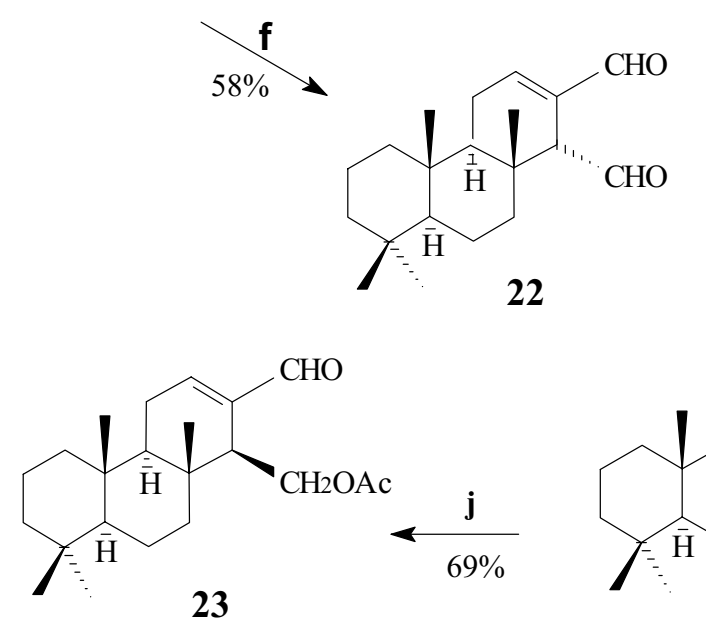

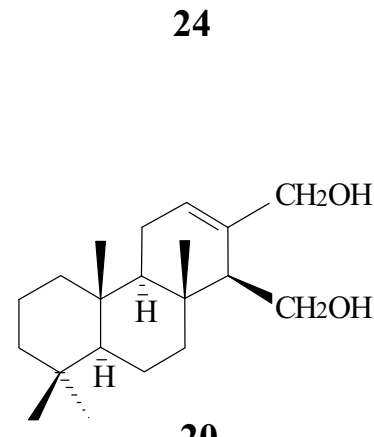

20

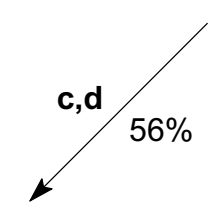

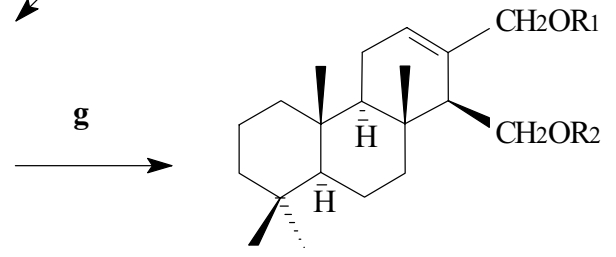
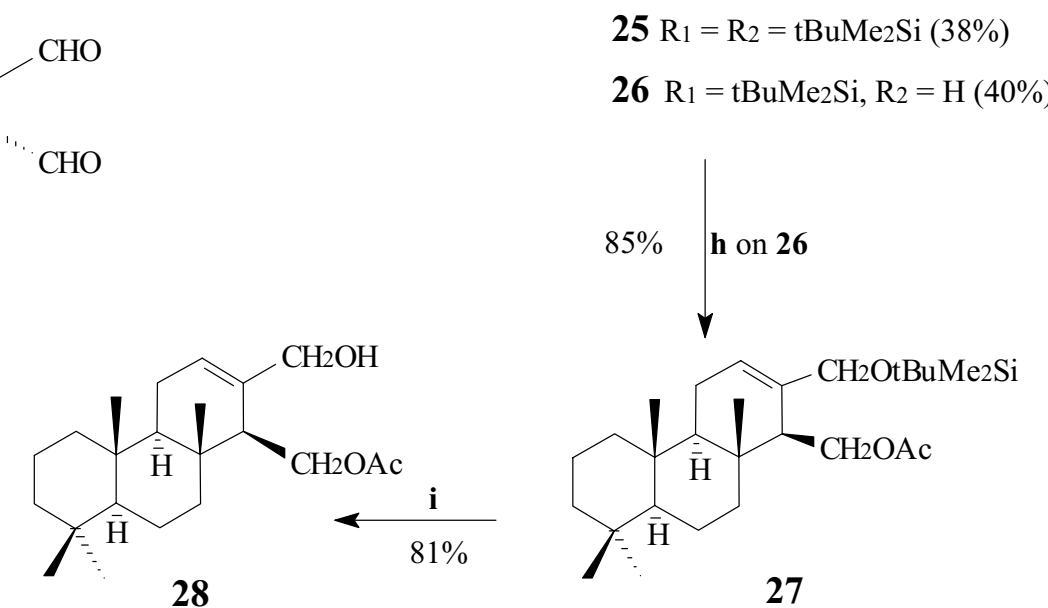

Scheme 3. syntheses of (+/-)-21, (+/-)-22 and (+/-)-23.

a. $\mathrm{MCPBA}, \mathrm{CH}_{2} \mathrm{Cl}_{2} ;$ b. $\mathrm{Al}\left(i\right.$-PrO) 3 , toluene, reflux; c. $6 \mathrm{~N}_{\text {aq H}} \mathrm{SO}_{4}$, dioxane 1:13; d. $\mathrm{LAH}$, Et2 2 ; e. DMSO, oxalyl chloride, $\mathrm{CH}_{2} \mathrm{Cl}_{2} ;$ f. basic alumina, $\mathrm{CH}_{2} \mathrm{Cl}_{2}$, r.t.; g. $t$-BuMe $2 \mathrm{SiCl}$, imidazole, DMF, $\mathrm{N}_{2}$; h. Ac2 $\mathrm{O}$, TEA / DMAP, r.t.; i. THF-AcOH- $\mathrm{H}_{2} \mathrm{O}$ (1:3:1), r.t.; j. $\mathrm{MnO}_{2}$, benzene 18 h. 


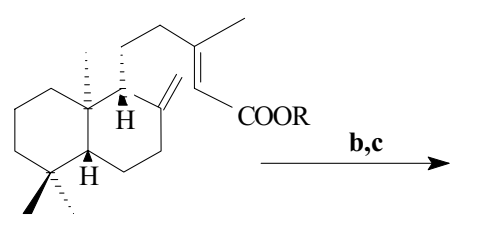

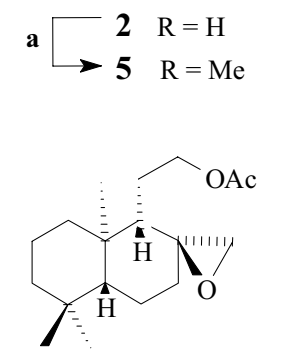

34

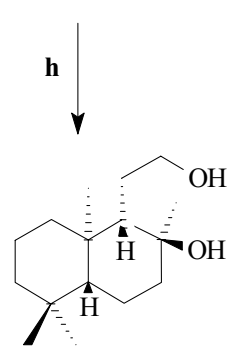

35

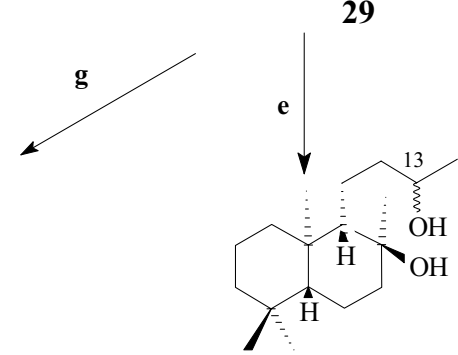

$36 \mathrm{C}-13(\mathrm{R})$

37 C-13 (S)

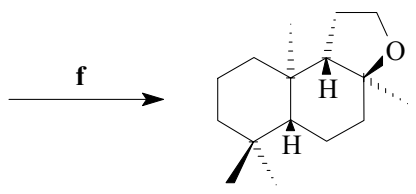

31

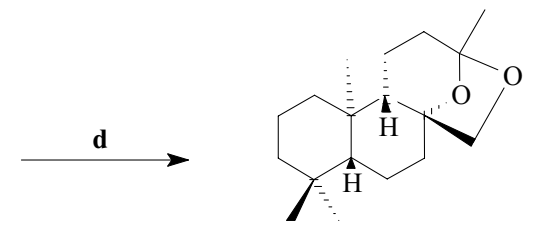

30

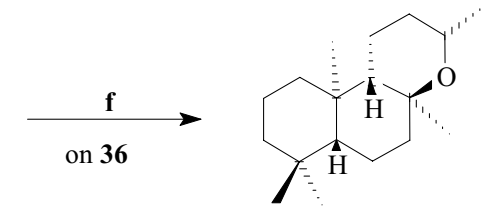

32

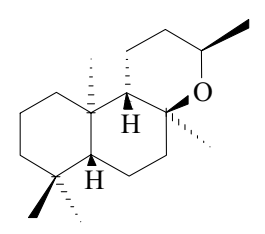

33

Scheme 4. Syntheses of ambergris-related compounds

a. $\mathrm{CH}_{2} \mathrm{~N}_{2}, \mathrm{Et}_{2} \mathrm{O}$; b. $\mathrm{MCPBA}, \mathrm{CH}_{2} \mathrm{Cl}_{2}(70 \%)$; c. $\mathrm{O}_{3}, \mathrm{CH}_{2} \mathrm{Cl}_{2},-78{ }^{\circ} \mathrm{C}$ then $\mathrm{Me}_{2} \mathrm{~S}(53 \%)$; d. $\mathrm{TsOH}$, benzene (54\%); e. $\mathrm{LAH}$, THF (43\% in 36 and $40 \%$ in 37); f. $\mathrm{MsCl}$, Py, benzene (66\% in 31 and 32,61\% in 33); g. $\mathrm{MCPBA}, \mathrm{CH}_{2} \mathrm{Cl}_{2}$, r.t., 7 days (32\%) and recovered material (32\%); h. $\mathrm{LAH}$, THF (97\%).

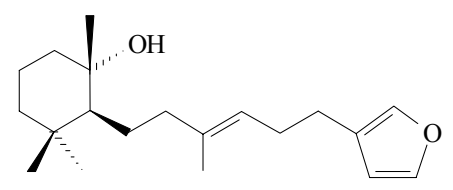

46 (ambliol-A)

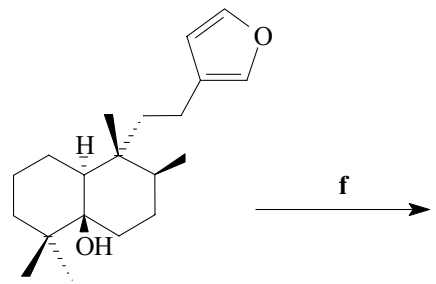

38 (ambliol-B)

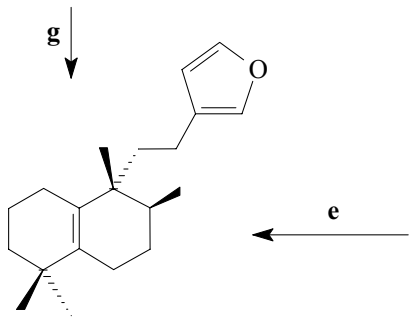

40
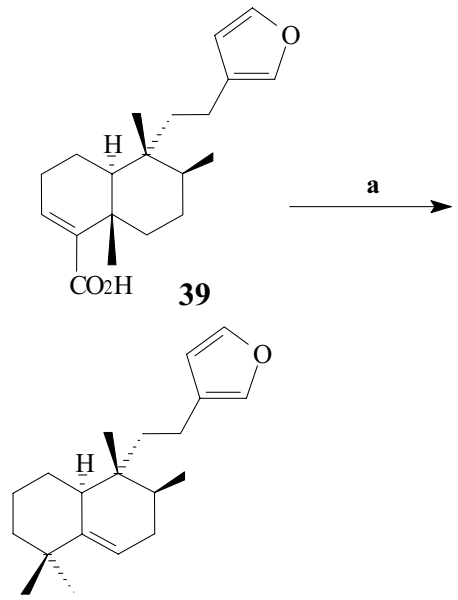

45

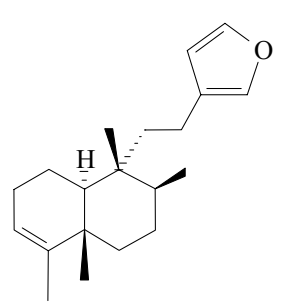

44
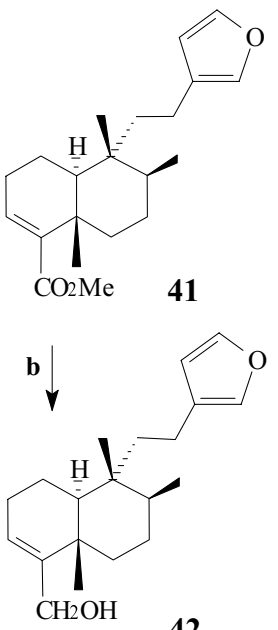

42

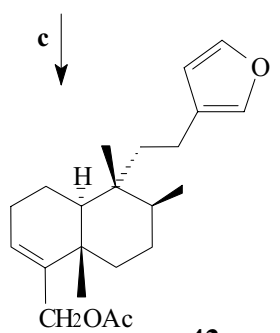

Scheme 5. Towards the synthesis of ambliol-B (38).

a. $\mathrm{CH}_{2} \mathrm{~N}_{2}, \mathrm{Et}_{2} \mathrm{O}$; b. $\mathrm{LAH}$, THF; c. $\mathrm{Ac}_{2} \mathrm{O} / \mathrm{Py}$; d. in situ nickel boride; e. $\mathrm{H}^{+}$; f. $\mathrm{POCl}_{3} / \mathrm{Py}$; g. $\mathrm{TsOH} /$ benzene. 
that there are two chemical varieties of Dysidea amblia, one containing ambliol-A (46) the other ambliol-B (38), that cannot be distinguished by classical taxonomic methods ${ }^{26}$.

\section{Sesquiterpenes}

Brasilenol (47) is a sesquiterpene that had been isolated from the sea hare Aplysia brasiliana, collected in the Gulf of Mexico, and also from the Mediterranean red alga Laurencia obtusa ${ }^{30}$. While not totally conclusive, this strongly suggested that brasilenol may be produced by the algae on which the mollusk grazes ${ }^{30}$. Because of its nonisoprenoid new skeleton, this compound was chosen as target for a total synthesis that should confirm the structure (derived from spectral data only) and establish the unknown absolute configuration. Racemic brasilenol was obtained through a selective synthesis, which required 11 steps from 4-isopropylphenol (51) and proceeded in about $5 \%$ overall yield (Scheme 6$)^{31}$. Phenol 51, itself, had been prepared in $67 \%$ from cumene (48) by classical nitration, reduction and diazotization ${ }^{32}$. Anisole $\mathbf{5 2}$ was then obtained from 51 by Claisen rearrangement of the derived crotyl ether followed by methylation. Standard hydroboration of the terminal olefin and Jones oxidation furnished a carboxylic acid, which smoothly cyclized to give the indone 53, by treatment with polyphosphoric acid. Partial reduction of the aromatic ring of 53 or $\mathbf{5 4}$, followed by dimethylation (and eventual double bond isomerization) and finally stereoselective reduction of the carbonyl group furnished racemic brasilenol (47).

Starting from $\beta$-pinene (59), the same group again synthesized racemic brasilenol (47), as shown in Scheme 7 , through a 16-step sequence in an approximate yield of
$0.5 \%^{32}$. The two major problems of this synthesis were first the Michael addition (step $i$ ) that produced a mixture of isomers, and second the isomerization of 69 into 74 in a 4 -step sequence of only $5 \%$ overall yield. Thus, it was assumed, from these results, that the gem-dimethyl group could be responsible for the observed lack of stereoselectivity of the Michael process, being however indispensable to insure the stereoselective reduction of brasilenone (74) to brasilenol $(\mathbf{4 7})^{32}$.

Finally, stereocontroled synthesis from (R)-(-)-cryptone (75) readily produced optically pure $(+)$-brasilenol $\left([\alpha]_{\mathrm{D}}+44.0^{\circ}\right.$, lit. $\left.+33.4^{\circ}\right)$ whose absolute configuration could thus be established as 3R,4S,7R (Scheme 8) ${ }^{33}$. The planned strategy used practically the same reactions as above, leaving the dimethylation for the penultimate step of the synthesis. The key step reaction resolved the uppermentioned problem of double bond isomerization using a palladium-hydrogen-induced migration of the double bond of 78 to 79 that not only delivered the required double bond isomer, but also the necessary trans relationship at C-3 and C-7.

Africanol (80) has been isolated from the Indonesian soft-coral Lemnalia africana and was the first terpenoid reported from alcyonarians ${ }^{34}$. Its intriguing new skeleton, determined by X-ray diffraction analysis ${ }^{34}$, and the rearrangements observed on acid treatment ${ }^{34,35}$ have triggered organic chemists. As a result, four syntheses have already been reported for that compound ${ }^{36-39}$. Two alternative methods have now been proposed. Both planned the construction of the five-membered ring in the final steps: the first methods followed a 9 -step procedure ${ }^{40}$, and the second a 10 -step one ${ }^{41}$. Scheme 9 depicts these syntheses. High
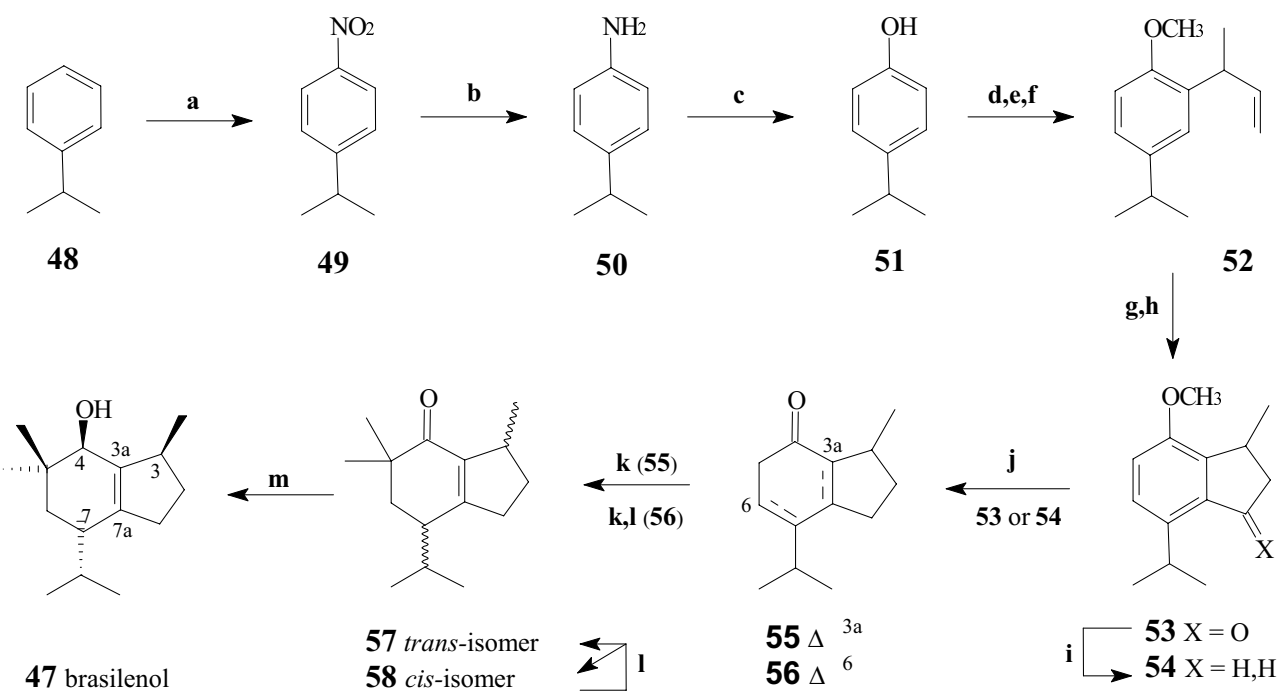

Scheme 6. Synthesis of racemic brasilenol from cumene.

a. $\mathrm{HNO}_{3}, \mathrm{CHCl}_{3}(98 \%)$; b. $\mathrm{SnCl}_{2}, \mathrm{HCl}, \mathrm{Et}_{2} \mathrm{O} ;$ c. $\mathrm{NaNO}_{2}, \mathrm{H}_{2} \mathrm{SO}_{4}(\mathrm{a}+\mathrm{b} 70 \%)$; d. $\mathrm{K}_{2} \mathrm{CO}_{3}, \smile \mathrm{Br}(97 \%)$; e. $\Delta(93 \%)$; f. $\mathrm{NaH}_{2} \mathrm{CH}_{3} \mathrm{I}(85 \%)$; g. $\mathrm{BH}_{3}$; $\mathrm{H}_{2} \mathrm{O}_{2}$, NaOH; Jones (73\%); h. PPA (63\%); i. $\mathrm{LAH} ; \mathrm{H}_{2}, \mathrm{Pd} / \mathrm{C}(97 \%)$; j. $\mathrm{Li}_{2} \mathrm{CH}_{3} \mathrm{NH}_{2}$, t-BuOH; $\mathrm{H}^{+}$; $\mathrm{SiO}_{2}$ separation (43\% from 156; 58\% from 157); k. $\mathrm{LDA}, \mathrm{CH}_{3} \mathrm{I}(\sim 83 \%)$; $\mathrm{SiO}_{2}$ separation; l. $\mathrm{RhCl}_{3}, \Delta, \mathrm{SiO}_{2}$ separation $(70-85 \%)$; m. $\mathrm{LiB}(\mathrm{Et})_{3} \mathrm{H}$, $\mathrm{THF}(73 \%)$. 

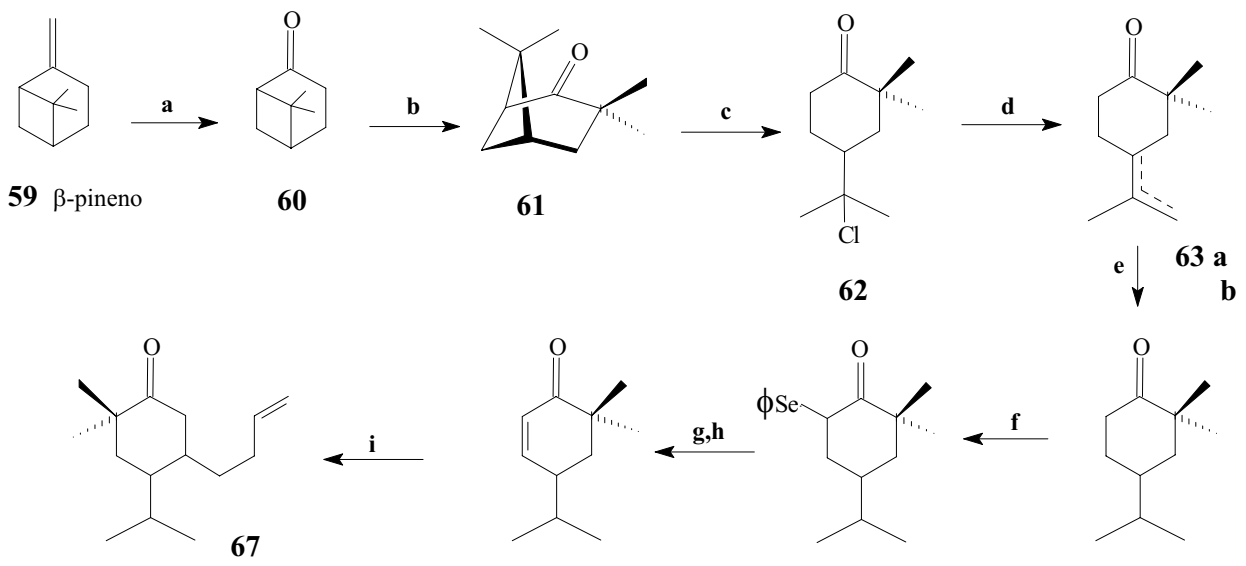

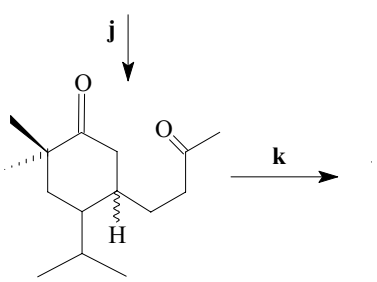

68

66

65

64

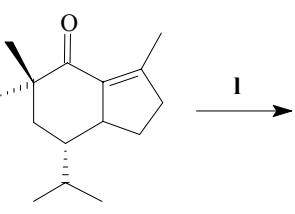

69

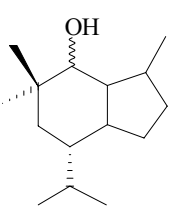

70
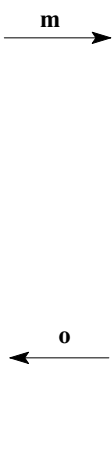

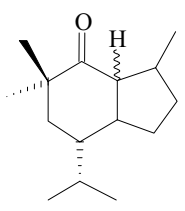

n

71

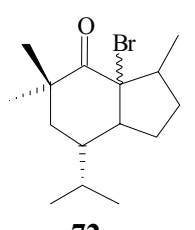

72

Scheme 7. synthesis of racemic brasilenol from $\beta$-pinene.

a. $\mathrm{O}_{3}, \mathrm{MeOH}, \mathrm{Me}_{2} \mathrm{~S},-78^{\circ} \mathrm{C}(86 \%)$; b. $\mathrm{KH}, \mathrm{CH}_{3} \mathrm{I}(93 \%)$; c. $\mathrm{HCl}$; d. $\mathrm{Py}$; e. $\mathrm{H}_{2} / \mathrm{PtO}_{2}, \mathrm{AcOEt}(91 \%)$; f. $\mathrm{PhSeCl},(\mathrm{Me} 3 \mathrm{Si}) 2 \mathrm{NLi}, \mathrm{THF},-78{ }^{\circ} \mathrm{C}(78 \%)$; g. $\mathrm{NaIO}_{4}, \mathrm{MeOH}, \mathrm{H}_{2} \mathrm{O}$; h. D (g,h = 73\%); i. $={ }^{\mathrm{MgBr}}, \mathrm{CuI}, \mathrm{THF},-20{ }^{\circ} \mathrm{C} \sim 0{ }^{\circ} \mathrm{C} 2 \mathrm{~h}(75 \%)$; j. $\mathrm{O}_{2} ; \mathrm{PdCl}_{2}, \mathrm{CuCl}, \mathrm{DMF}, \mathrm{H}_{2} \mathrm{O}, \mathrm{THF}, 3 \mathrm{~h}(79 \%) ; \mathbf{k} .3 \%$ $\mathrm{NaOH}$, $\mathrm{EtOH}(60 \%)$; l. $\mathrm{Li}$, $\mathrm{NH}_{3}$ liq. (62\%); m. $\mathrm{CrO}_{3}, \mathrm{Py} \mathrm{CH}_{2} \mathrm{Cl}_{2}(58 \%)$; n. $\mathrm{Br} 2, \mathrm{AcOH}(90 \%)$; o. $\mathrm{LiCO}_{3}, \mathrm{DMF}(50 \%)$; p. $\mathrm{LiB}(\mathrm{Et}) 3 \mathrm{H}, \mathrm{THF}$.

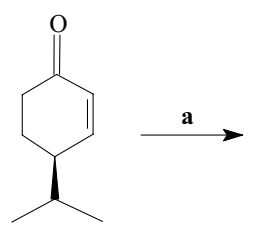

75 (R)-(-)-cryptone

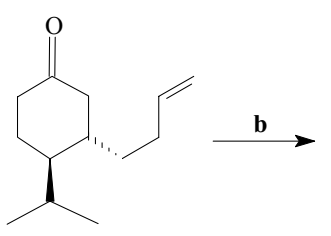

76

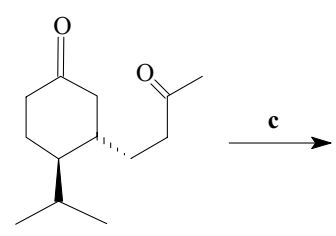

77

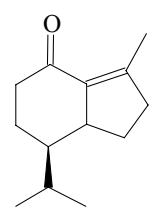

78

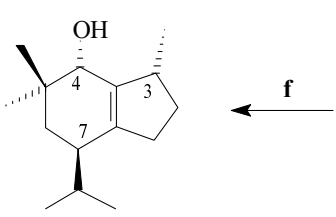

$47(+)$-brasilenol

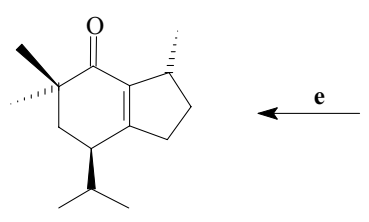

72

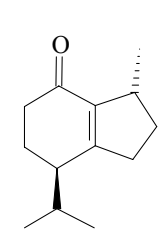

79

$$
3 \mathrm{R}, 4 \mathrm{~S}, 7 \mathrm{R}
$$

Scheme 8. synthesis of (+)-brasilenol from (R)-(-)-cryptone.

a. ${ }_{\mathrm{MgBr}}, \mathrm{CuI}, \mathrm{THF}(97 \%)$; b. $\mathrm{PdCl}_{2}, \mathrm{CuCl}, \mathrm{O}_{2}, \mathrm{DMF}-\mathrm{H}_{2} \mathrm{O}(79 \%)$; c. t-BuOK / t-BuOH (84\%); d. 10\% $\mathrm{Pd} / \mathrm{C}, \mathrm{H}_{2}$, benzene $(63 \%)$; e. $\mathrm{LiN}(\mathrm{PPr}) 2$, THF, $\mathrm{CH}_{3} \mathrm{I}(84 \%)$; f. $\mathrm{LiB}(\mathrm{Et})_{3} \mathrm{H}$, THF (92\%).

stereoselectivity was observed on alkylation of the dimethylhydrazone derived from $\mathbf{8 2}(\operatorname{method} \mathrm{A})^{40}$. On the other hand, cyclization of $\mathbf{8 7}$ lacked stereoselectivity and yielded isomers 80,88 and 89 in a 1:0.6:1 ratio $(\operatorname{method} B)^{41}$. 
Dactylol (90) is an irregular isoprenoid alcohol isolated from the digestive glands of the Caribbean sea hare Aplysia dactylomela and from its putative dietary source, the red alga Laurencia poitei collected in the Florida Keys ${ }^{42}$. As with africanol (80), dactylol is assumed to be biosynthetically derived from humulene (91) as illustrated in Scheme $10^{34,43}$. Although highly uncommon and a priori question- able, the 1,2-migration of the cyclopropane ring of 95 into 96 has been successfully achieved using $\mathrm{BF}_{3} . \mathrm{OEt}_{2}$ in $\mathrm{Et}_{2} \mathrm{O}$ at $-10{ }^{\circ} \mathrm{C}^{43}$.

Dactylol is one of the simplest members of the interesting family of natural products possessing a cyclooctanoid structure. Such substances are the object of great interest ${ }^{44}$. Two syntheses of racemic dactylol (90) have already been

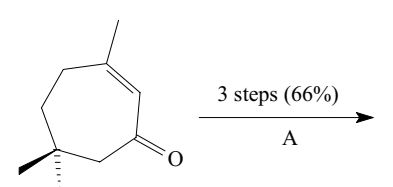

81

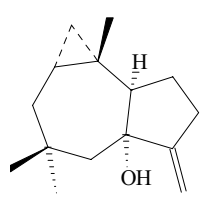

84

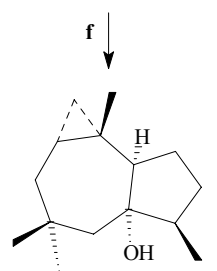

80 africanol

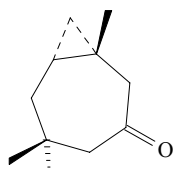

82 $\mathbf{a}, \mathbf{b}, \mathbf{c}$
$(30 \%)$<smiles>C=C(CC[C@H]1C(=O)CC(C)(C)CC2C[C@@]21C)SCC</smiles>

83

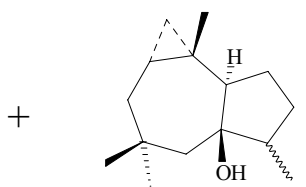

$88 \beta-\mathrm{Me}$ $89 \alpha-\mathrm{Me}$

B

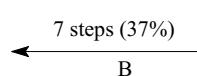

g

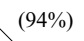

$\longleftarrow \mathbf{k}$

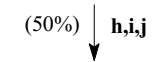

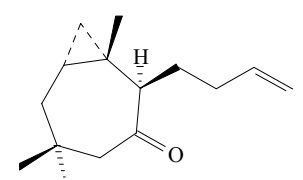

87

Scheme 9. Syntheses of africanol.

a. $\mathrm{DMH}$, benzene; b. LDA, THF, RI; c. $\mathrm{NaIO}_{4}$, THF, $\mathrm{H}_{2} \mathrm{O}$; d. $\mathrm{I}_{2}, \mathrm{CH}_{2} \mathrm{Cl}_{2}$; e. n-BuLi, THF; f. $\mathrm{H}_{2} / \mathrm{PtO}_{2}$, EtOAc; g. $\mathrm{Me}_{2} \mathrm{NNH}_{2}$, benzene, $80{ }^{\circ} \mathrm{C}$; h. n-BuLi, THF, $0{ }^{\circ} \mathrm{C}$; i. $\mathrm{RI}, 20{ }^{\circ} \mathrm{C}$; j. $\mathrm{H}_{3} \mathrm{O}^{+}$; k. $\mathrm{SmI}_{2}, \mathrm{THF}, \mathrm{HMPA}$.

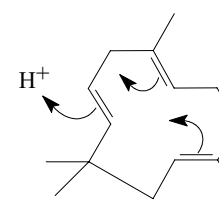

91 humulene

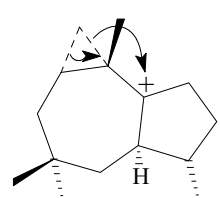

95
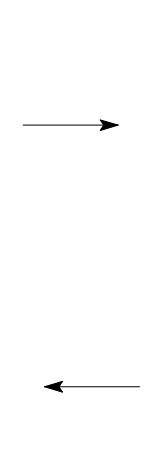

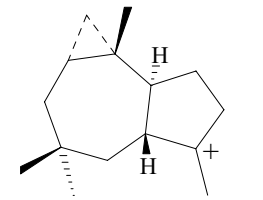

92

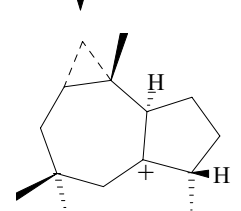

94
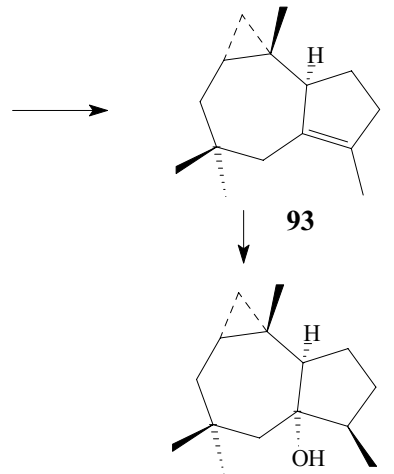

80 africanol

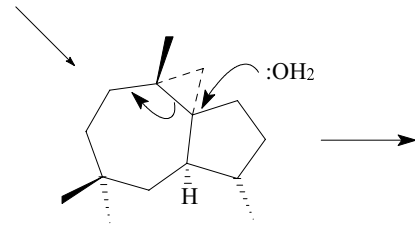

96

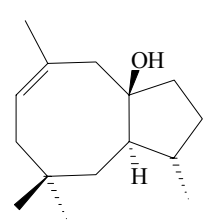

90 dactylol

Scheme 10. biosynthetic proposal for africanol and dactylol. 
reported $^{37,45}$. Both used ring expansion methodology. Total synthesis of $(+)$-dactylol has now been reported and proceeds via a novel $[3+5]$ annulation ${ }^{46}$. An alternative methodology planned the preparation of the skeleton 90, through an intramolecular reductive coupling of keto-aldehyde (103) as shown in Scheme 11 47,48. Although the carbonyl coupling appears direct, the potential lability of the $\beta$-hydroxy ketone moiety in $\mathbf{1 0 3}$ could prove troublesome. The model substrate $\mathbf{1 1 1}$ was thus prepared to first investigate the McMurry low-valent titanium promoted coupling (Scheme 11, step n) ${ }^{49}$. This coupling indeed proceeded, but in rather low yields $(\sim 10 \%)$ under a number of different experimental conditions ${ }^{49}$.

The sesquiterpene hydrocarbon caridiene (112), a major constituent of the volatile fraction from the Cuban gorgonian Pseudopterogorgia americana ${ }^{50}$, was the target of a total synthesis starting from a cycloaddition between myrcene (113) and methyl-vinyl ketone (114). Isocaridiene (118) was obtained by acid-catalyzed cyclization, Grignard reaction and dehydration (Scheme 12$)^{51}$. Attempts to isomerise 118 to 112 were unsuccessful.

The dorid nudibranch Acanthodoris nanaimoensis, collected in British Columbia, produces three aldehydic ses-<smiles>CC(C)=CCO</smiles>

97<smiles>C=CC(C)(C)CC=O</smiles>

98
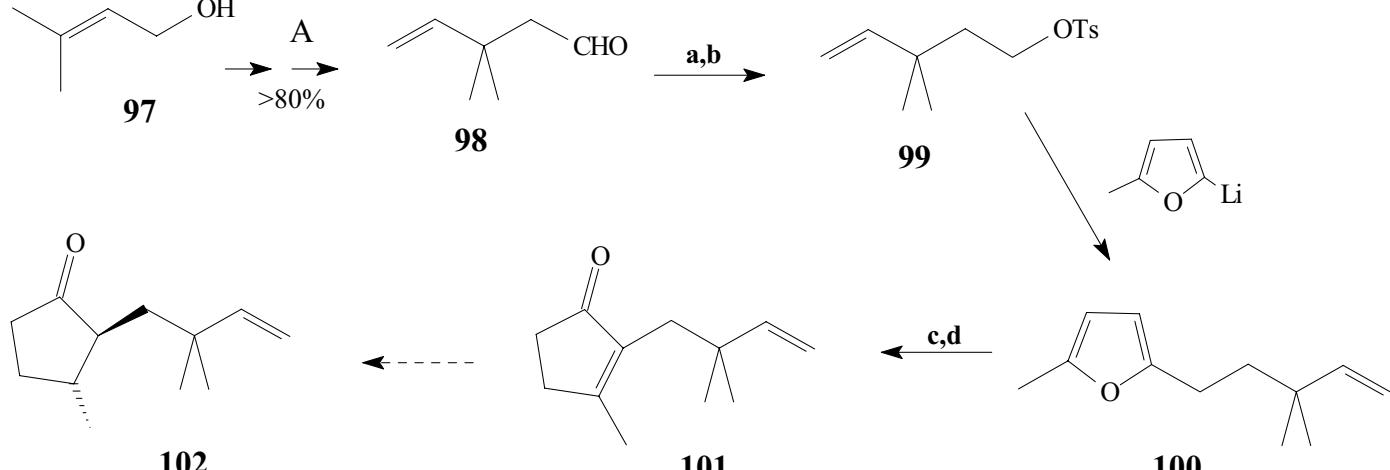

102

101

100

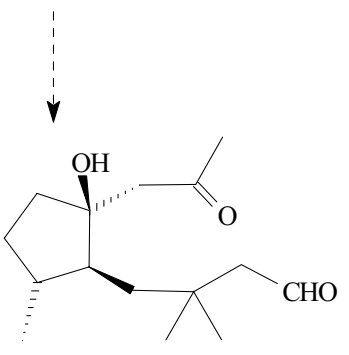

103

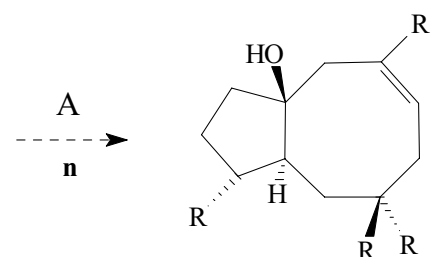

$90 \mathrm{R}=$ Me dactylol $(\mathrm{A})$ $111 \mathrm{R}=\mathrm{H}(\mathrm{B})$

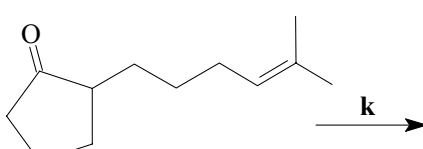

108
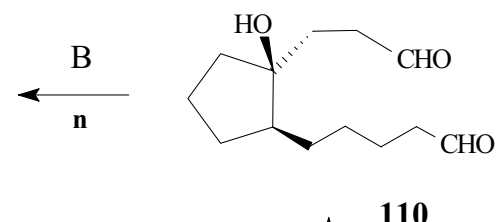

个

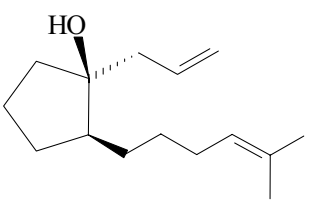

109

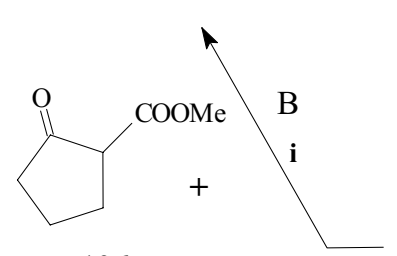

106

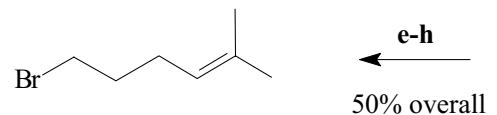

105

$50 \%$ overall

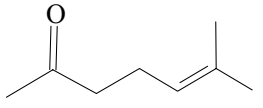

104

Scheme 11. Toward the synthesis of dactylol.

a. $\mathrm{NaBH}_{4}, \mathrm{THF}-\mathrm{H}_{2} \mathrm{O}$; b. $\mathrm{TsCl}, \mathrm{CHCl}_{3}$, $\mathrm{Py}$; c. $\mathrm{H}^{+} / \mathrm{H}_{2} \mathrm{O}$; d. aldolization; e. $\mathrm{NaOBr}, \mathrm{NaOH}$, dioxane $/ \mathrm{H}_{2} \mathrm{O}, 4{ }^{\circ} \mathrm{C}, 1$ h then $\mathrm{NH}_{4} \mathrm{Cl}(64 \%)$; f. $\mathrm{LAH}$, THF, reflux, $3 \mathrm{~h}(90-93 \%)$; g. MsCl, Et3N $\mathrm{CH}_{2} \mathrm{Cl}_{2},-10{ }^{\circ} \mathrm{C}, 5-10 \mathrm{~min}(97-99 \%)$; h. $\mathrm{LiBr}$, THF, reflux, $3 \mathrm{~h}(86-89 \%)$; i. $\mathrm{K}_{2} \mathrm{CO}_{3}$, acetone, reflux, $60 \mathrm{~h}(78 \%)$; j. $\mathrm{KCN}, \mathrm{DMSO}, 150{ }^{\circ} \mathrm{C}, 2 \mathrm{~h}(76 \%)$; k. ${ }_{\mathrm{Br}} \quad, \mathrm{MgCl}_{2}$, K, THF, r.t. (77\%); l. DMAP, NHiPr $2, \mathrm{MEM}-\mathrm{Cl}$, r.t. 14 h $(92 \%) ; \mathbf{m} . \mathrm{O}_{3}, \mathrm{CH}_{2} \mathrm{Cl}_{2},-78{ }^{\circ} \mathrm{C}$, then $\mathrm{Me}_{2} \mathrm{~S}-78^{\circ} \mathrm{C}$ or $\mathrm{H}_{2}$, Pd-C 60 psi, r.t., 4 h (60\%); n. TiCl $/$ K-graphite (1/3), DME, r.t. $40 \mathrm{~h}$ and reflux $5 \mathrm{~h} \mathrm{(10 \% ).}$ 


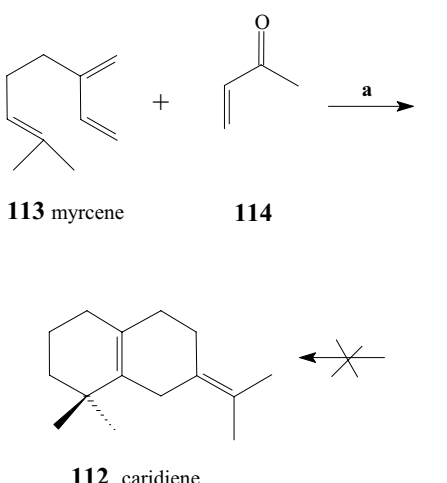

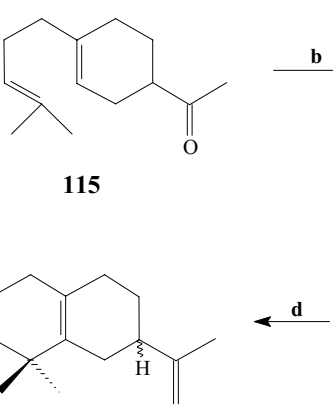

118

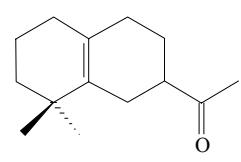

116

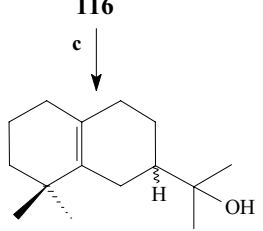

117

Scheme 12. Synthesis of isocaridiene.

a. $\mathrm{TiCl}_{4}$, toluene $(80 \%)$; b. $\mathrm{HCOOH}, 80{ }^{\circ} \mathrm{C}(85 \%)$; c. MeMgI, ether $(70 \%)$; d. $\mathrm{TsOH}$, benzene $(75 \%)$.

quiterpenes $^{52}$. Nanaimoal (119), the major component, probably acts to control predation. Its structure was established from spectral data and synthesis, from myrcene (113), of its p-bromo-phenyl-urethane derivative ${ }^{52}$. A short communication reports a similar total synthesis of $\mathbf{1 1 9}$, following Scheme $13^{53}$. Thus, Diels-Alder reaction between myrcene (113) and methyl methacrylate (120) gave a mixture of regioisomeric esters 121 and 122, that was subsequently reduced with lithium aluminium hydride to a 3:1 mixture of primary alcohols 123 and 124. Acid-catalyzed cyclization of the less abundant 124 into 125 followed by tosylation, cyanation and reduction with DIBAL furnished racemic nanaimoal (119). The key step in this synthesis was claimed to be the separation of the regioisomers 123 and 124. Racemic nanaimoal has been obtained recently via Diels-Alder reaction of methacrylate with 1,1dimethyl-2,3-dimethylenecyclohexane, a novel building block for cyclic terpenoids ${ }^{54}$.
The eudesmane sesquiterpene $(+)$-coralloidin-A (127) was isolated from the Mediterranean soft coral Alcyonium coralloides living on a gorgonian of the genus Eunicella ${ }^{55}$. It was the first naturally occurring 5,6-dehydro-eudesmane to be described. Racemic coralloidin-A has now been synthesized in a seven-step sequence from the known enone 131, as depicted in Scheme $14^{56}$. The first step was the acetoxylation of enone $\mathbf{1 3 1}$ into the key intermediate $\mathbf{1 3 2}$. The acetate of $\mathbf{1 3 2}$ was then hydrolysed and oxidized to the unsaturated $\alpha$-diketone 133, and the enol form methylated, in low yield (62\%), to the methoxy derivative 134. Wittig addition of $\mathrm{a} \mathrm{C}_{3}$ unit completed the sesquiterpene skeleton and proceeded satisfactorily (79\% after chromatographic purification). Reduction of the keto group furnished alcohol 136 in the desired $\beta$-orientation. The stereoselectivity of this reduction is probably controlled by the angular methyl group. Finally, acetylation of $\mathbf{1 3 6}$ gave racemic coralloidin-A in an overall yield, calculated from 131, of about $30 \%{ }^{57}$.
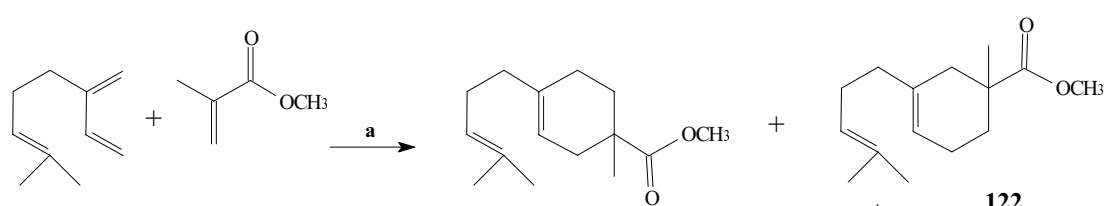

113 myrcene

120

121

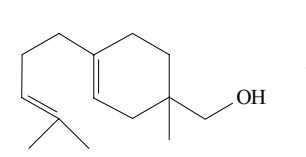

123

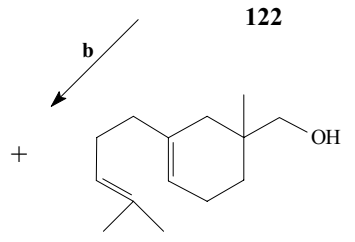

124

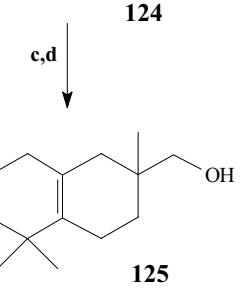

119 nanaimoal

Scheme 13. Synthesis of (+/-)-nanaimoal.

a. $\Delta, 130{ }^{\circ} \mathrm{C}, 24 \mathrm{~h}$; b. $\mathrm{LAH}, \mathrm{Et} 2 \mathrm{O}$; c. chromatography; d. $\mathrm{HCOOH}, 60^{\circ} \mathrm{C}$; e. $\mathrm{TsCl}$, Py; f. $\mathrm{NaCN}, \mathrm{HMPA}$; g. DIBAL, hexane. 


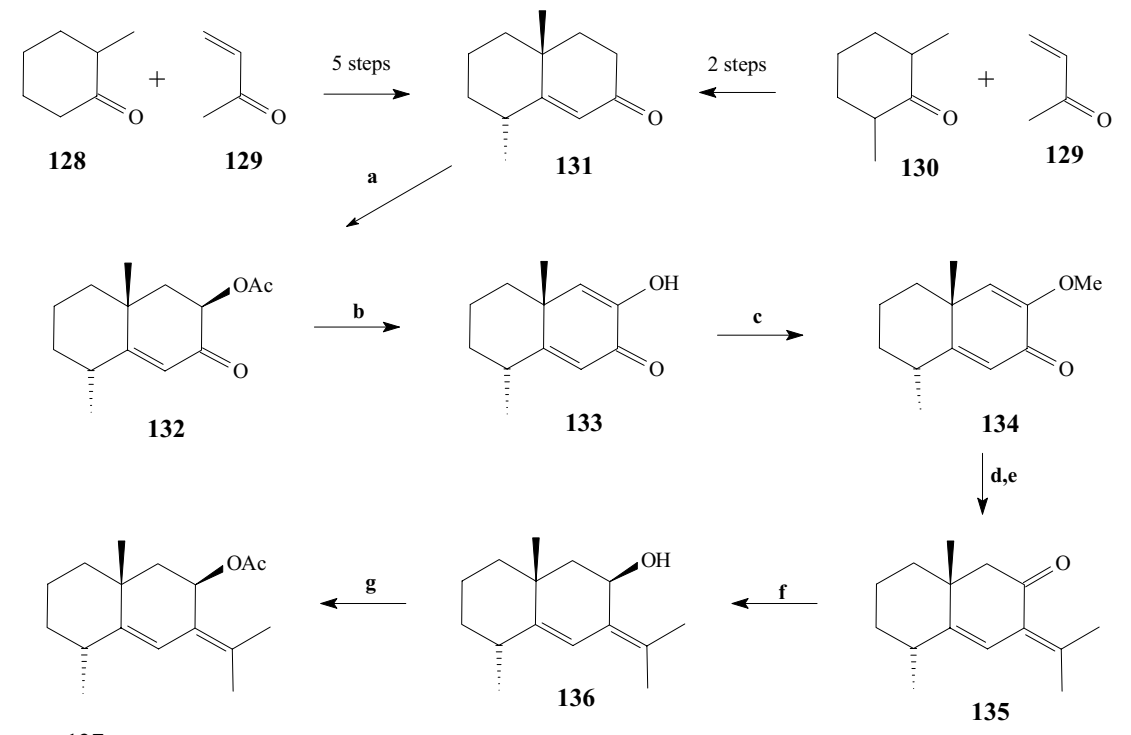

Scheme 14. Synthesis of coralloidin-A.

a. $\mathrm{Mn}(\mathrm{OAc})_{3} .2 \mathrm{H}_{2} \mathrm{O}$, benzene (82\%); b. $\mathrm{KOH}, \mathrm{MeOH}, \mathrm{O}_{2}(86 \%)$; c. t-BuOK, t-BuOH, MeI (62\%); d. $\mathrm{PPrPh}_{3} \mathrm{Br}$, Et 2 O, THF; e. chromatography (79\% from 134); f. $\mathrm{LAH}, \mathrm{Et}_{2} \mathrm{O}$; g. $\mathrm{Ac} 2 \mathrm{O}, \mathrm{DMAP}, \mathrm{CH}_{2} \mathrm{Cl}_{2}$.

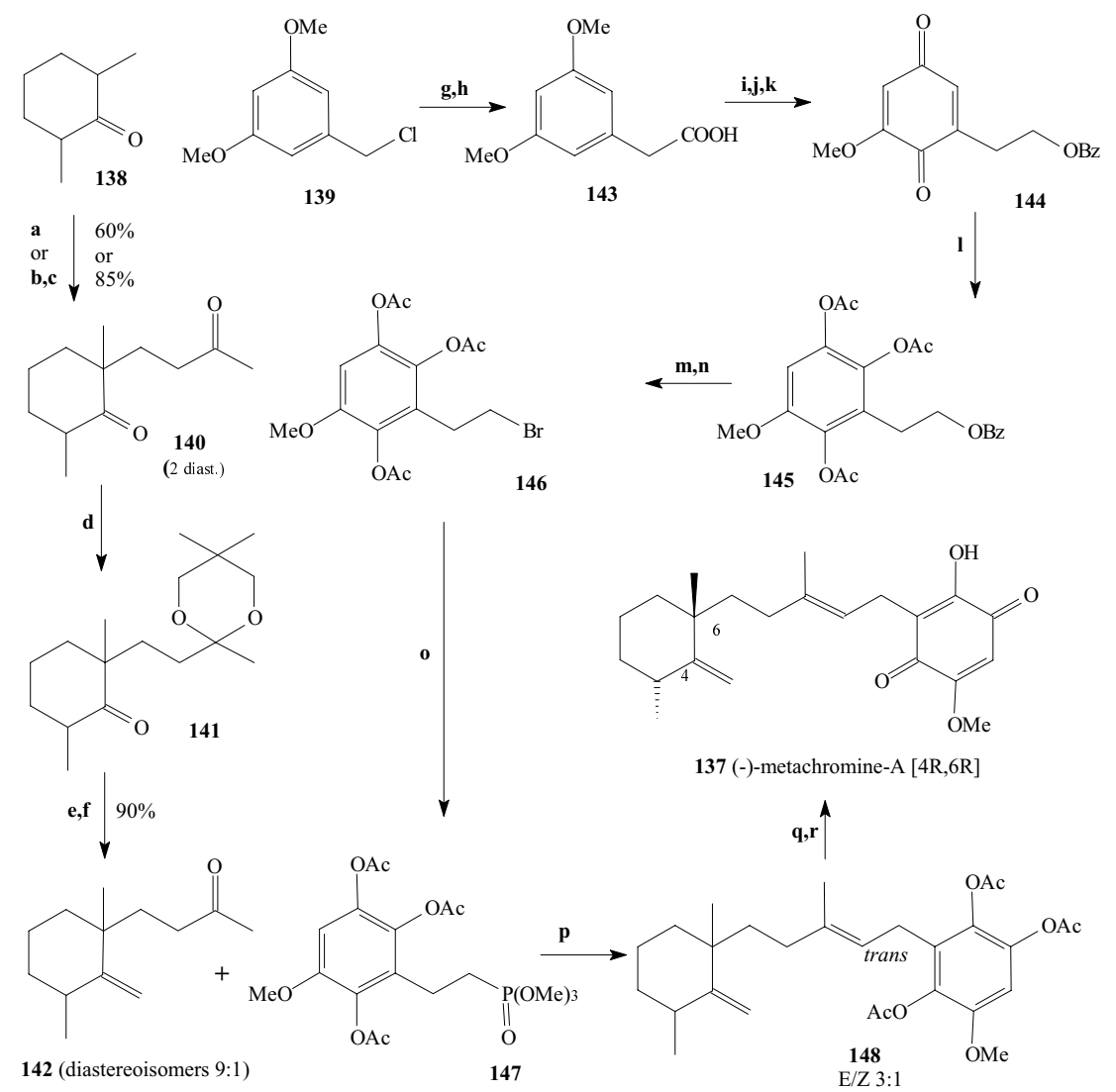

Scheme 15. synthesis of metachromine-A.

a. $\mathrm{H}_{2} \mathrm{SO}_{4}$ conc., MVK, benzene (53\%); b. $\mathrm{Et}_{3} \mathrm{~N}$, TMSCl, $\mathrm{NaI}, \mathrm{CH}_{3} \mathrm{CN}(82 \%)$; c. $\mathrm{MVK}, \mathrm{BF}_{3}$. $\mathrm{Et}_{2} \mathrm{O}, \mathrm{MeNO}_{2}$, menthol (85\%); d. p-TsOH, но $>$ он, benzene, r.t. (95\%); e. $\mathrm{Ph}_{3} \mathrm{PBr}, \mathrm{CH}_{3} \mathrm{I}$, t-BuOK, benzene (80\%); f. PPTS, toluene (90\%); g. $\mathrm{NaCN}$, EtOH- $\mathrm{H}_{2} \mathrm{O}$, reflux, 4 h (93\%); h. $\mathrm{NaOH}(40 \%)$, $\mathrm{H}_{2} \mathrm{O}_{2}$ reflux (90\%); i. LAH, THF, reflux (98\%); j. NaH, THF then $\mathrm{BzBr}$, reflux (84\%); k. $\mathrm{CrO}_{3}, \mathrm{AcOH}_{2} \mathrm{H}_{2} \mathrm{O} 0{ }^{\circ} \mathrm{C}$ then r.t. 2 h $(84 \%) ; \mathbf{l}$. $\mathrm{Ac}_{2} \mathrm{O}$, $\mathrm{H}_{2} \mathrm{SO}_{4}$, r.t., $12 \mathrm{~h}(65 \%)$; m. $\mathrm{H}_{2}$, Pd-C, $\mathrm{AcOH}$, r.t., 12 h (85\%); n. $\mathrm{CBr}_{4}-\mathrm{Ph}_{3} \mathrm{P}, \mathrm{CH}_{2} \mathrm{Cl}_{2}, 0^{\circ} \mathrm{C}$ then r.t., $6 \mathrm{~h}(80 \%)$; o. (MeO) 3 P, DME, reflux, 3 h (56\%); p. i. 147 in THF, $-78{ }^{\circ} \mathrm{C}, \mathrm{nBuLi}, 30 \mathrm{~min}$ then add 142 in THF $(60 \% \mathrm{E} / \mathrm{Z})$ or ii. $147 \mathrm{NaH}$, THF $0{ }^{\circ} \mathrm{C}$ then r.t. $30 \mathrm{~min}$ add 142 in THF, reflux, $4 \mathrm{~h}(40 \% \mathrm{E})$; q. $\mathrm{LAH}$, $\mathrm{Et}_{2} \mathrm{O}, 0{ }^{\circ} \mathrm{C}(55 \%)$; r. $1 \%$ aq. $\mathrm{FeCl}_{3}$, benzene, r.t., $20 \mathrm{~min}(65 \%)$. 
(-)-Metachromin-A (137) is one of the sesquiterpenoid quinones with an unprecedent skeleton that has been isolated from the Okinawan sponge Hippospongia cf. metachromia ${ }^{58}$. It exhibits a potent antitumor activity against L-1210 leukemia cells in vitro $\left(\mathrm{IC}_{50} 2.40 \mu \mathrm{g} / \mathrm{ml}\right)$ and potent coronary vasodilating activity in rabbit isolated artery $\left(\mathrm{IC}_{50} 3 \times 10^{-6} \mathrm{M}\right)^{58}$. Convergent synthesis of metachromin-A from 2,6-dimethylcyclohexanone (138) and the benzyl chloride 139 was achieved through the 16 -step process shown in Scheme 15 $5^{59-61}$. Thus, Michael

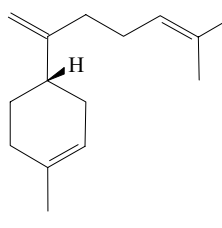

151

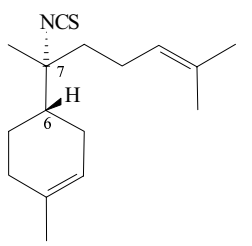

149

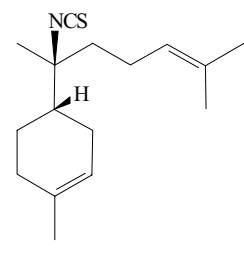

150

Scheme 16. Synthesis of a Halichondria metabolite (ent-149).

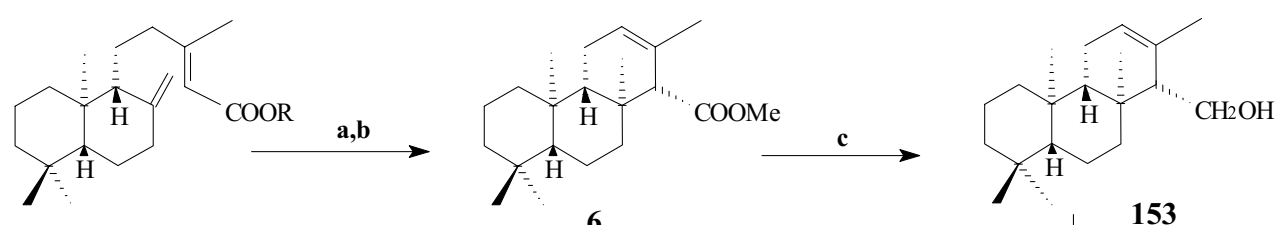

$2 \mathrm{R}=\mathrm{H}$ copalic acid

6

153

$5 \mathrm{R}=\mathrm{Me}$

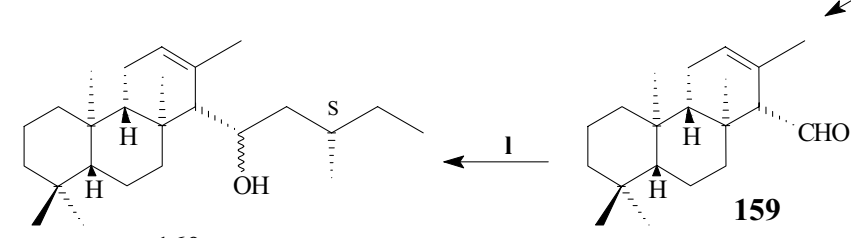<smiles>CC[C@H](C)CC(=O)[C@H]1C(C)=CC[C@H]2[C@@H]1CC[C@H]1[C@@H](C)CCC[C@@]12C</smiles><smiles>CCOCCNC(=O)OCC</smiles>

d<smiles>CC1([V])C=CC=C1</smiles>

$\uparrow$

152 ent-hyrtiosal<smiles>C[13CH]</smiles><smiles>COC[C@H]1C(C)=CC[C@H]2[C@H]1CCCC2(C)C</smiles><smiles>CC[C@H](C)CC(=O)[C@H]1[C@@H]2CC[C@H]3C(C)(C)CCC[C@]3(C)[C@H]2C[C@H]2O[C@]12C</smiles>

162

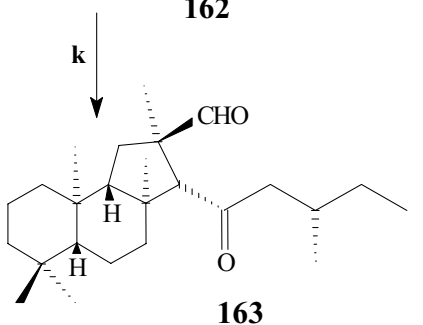

164

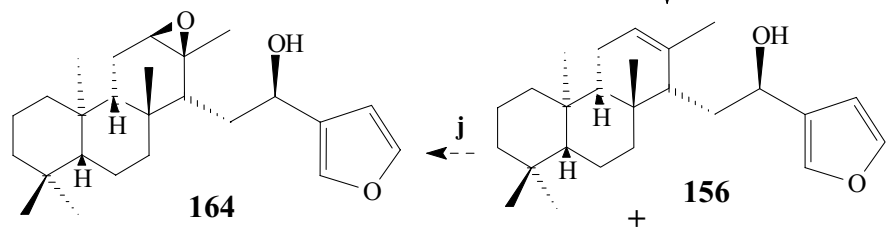

156<smiles>CC1=CC[C@H]2[C@@H](CC[C@H]3[C@@H](C)CCC[C@H]32)[C@@H]1CC#N</smiles>

f,g $\rfloor 62 \%$

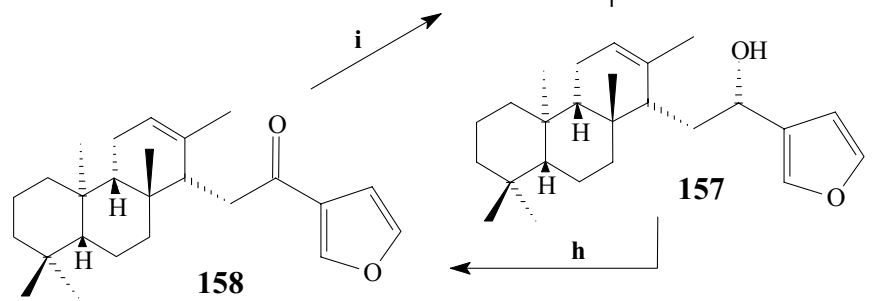

163

Scheme 17. Toward the synthesis of ent-hyrtiosal.

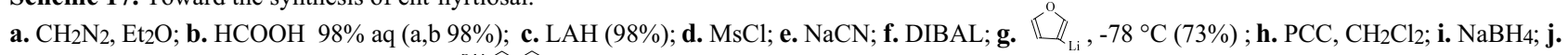
$\mathrm{MCPBA}, \mathrm{CHCl}_{3} ; \mathbf{k} \cdot \mathrm{BF}_{3} \cdot \mathrm{Et}_{2} \mathrm{O}$, benzene; l. $\stackrel{\mathrm{Brmg}}{\overbrace{(}}(62 \%)$. 
addition of methylvinylketone on 138 furnished 140 as a 7:3 mixture of diastereoisomers. Protection of the less hindered keto group, olefination and removal of the protecting group yielded ketone 142 (two diastereoisomers) in $47 \%$ overall yield. On the other hand, quinone 144 was prepared from the commercially available benzyl chloride 139 by cyanation, basic hydrolysis to the corresponding acid, LAH reduction, protection of the primary alcohol and chromic acid oxidation of the aromatic ring. Then, Thiele acetoxylation followed by hydrogenolysis of the benzyl group, substitution by a bromine and phosphonation via a Michaelis-Arbuzov reaction delivered, in $\sim 6 \%$ overall yield, the desired intermediate 147 that was subsequently coupled (HWE reaction) to ketone $\mathbf{1 4 2}$ affording a 3:1 mixture of the E/Z isomers. Metachromine-A (137) was finally obtained by reduction of the acetate groups and smooth ferric chloride oxidation in $16 \%$ yield from the coupling of 142 and $147^{61}$.

A number of isothiocyanosesquiterpenes have been isolated from sponges or from mollusks that feed on them ${ }^{62}$. Recently, an efficient methodology to introduce a tertiary NCS group has been described using in situ generated HSCN and mild operating conditions ${ }^{63}$. This eventually led to the synthesis of $(6 \mathrm{~S}, 7 \mathrm{R})$ and $(6 \mathrm{~S}, 7 \mathrm{~S})$-7-isothiocyano-7,8dihydro- $\alpha$-bisabolene 149 and $\mathbf{1 5 0}$, the former being the enantiomer of a marine metabolite from an unspecified Halichondria sponge ${ }^{64}$ and not from a Ciocalypta sponge $^{65}$ as reported $^{66}$ (see Scheme 16).
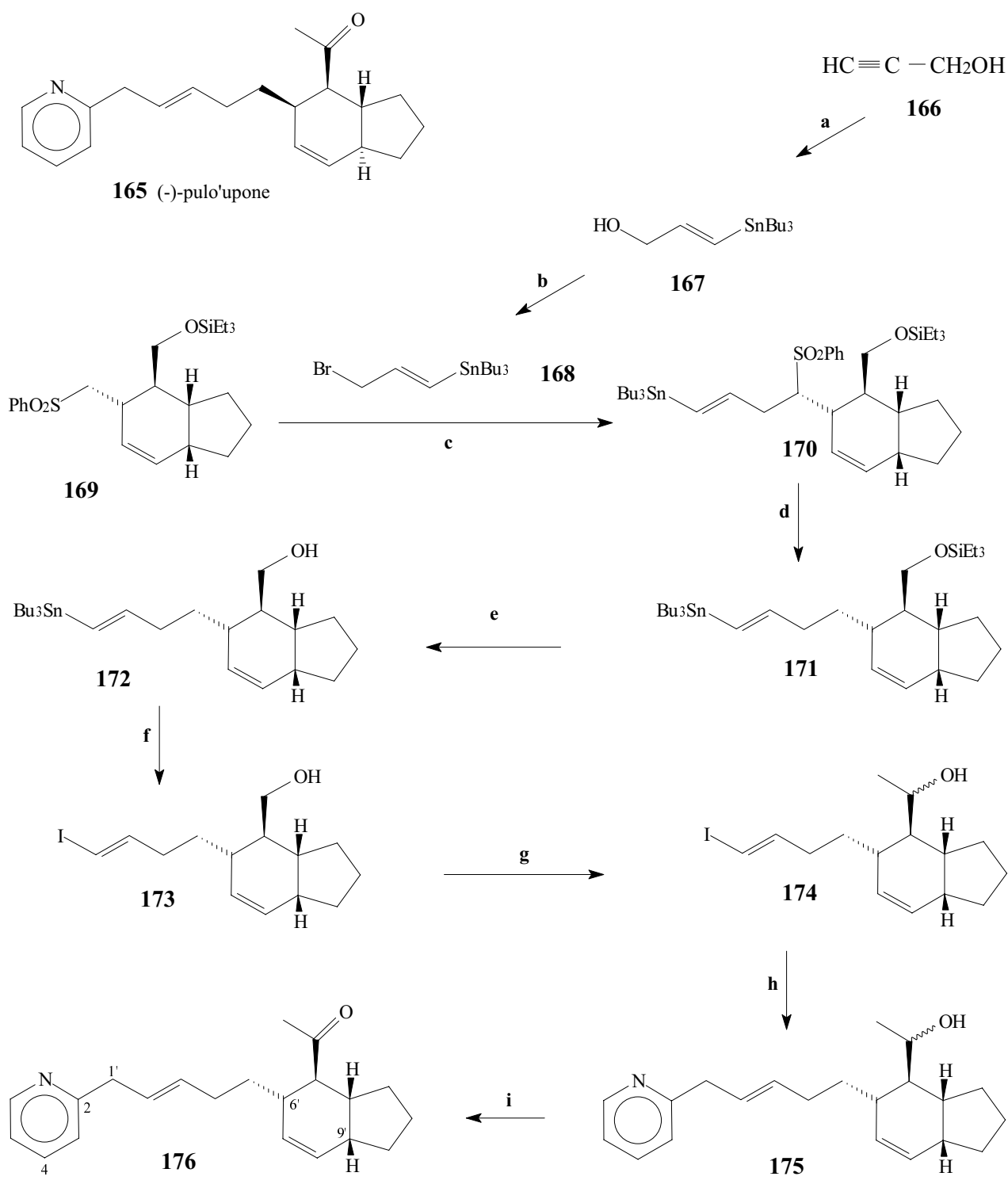

Scheme 18. Synthesis of pulo'upone side chain.

a. $\mathrm{Bu}_{3} \mathrm{SnH}, \mathrm{AIBN}, 80^{\circ} \mathrm{C}, 2 \mathrm{~h}(50 \%)$; b. $\mathrm{PPh}_{3}, \mathrm{CBr}_{4}, \mathrm{CH}_{2} \mathrm{Cl}_{2},-20^{\circ} \mathrm{C}$ to r.t., 5 h (55\%); c. n-BuLi, THF, HMPA, $-78{ }^{\circ} \mathrm{C}(42 \%)$; d. $6 \% \mathrm{Na}(\mathrm{Hg}), \mathrm{Na} 2 \mathrm{HPO}$, $\mathrm{MeOH}, 0{ }^{\circ} \mathrm{C}(76 \%)$; e. $\mathrm{Bu} 4 \mathrm{~N}$, THF $(90 \%)$; f. $\mathrm{I}_{2}, \mathrm{CH}_{2} \mathrm{Cl}_{2},-78{ }^{\circ} \mathrm{C}$ to $0{ }^{\circ} \mathrm{C}(88 \%) ; \mathbf{g} .(\mathrm{COCl}) 2$, DMSO, Et $3 \mathrm{~N}, \mathrm{THF},-78{ }^{\circ} \mathrm{C}$ to $-35^{\circ} \mathrm{C} ; \mathrm{MeMgBr}(70 \%) ; \mathbf{h}$. $\left\langle\mathrm{O}^{\mathrm{N}} \mathrm{CH}^{-\mathrm{H}_{3}}, \mathrm{n}-\mathrm{BuLi}, \mathrm{THF}, 0{ }^{\circ} \mathrm{C}\right.$; $\mathrm{CuCN}$, THF, $-78{ }^{\circ} \mathrm{C}(83 \%)$; i. $(\mathrm{COCl})_{2}$, DMSO, $\mathrm{Et}_{3} \mathrm{~N}, \mathrm{CH}_{2} \mathrm{Cl}_{2},-60{ }^{\circ} \mathrm{C}(82 \%)$ 


\section{Miscellaneous}

Hyrtiosal (152) is a sesterterpene isolated from the marine sponge Hyrtios erectus (= erecta?) and belongs to a new class of terpenoid named hyrtiosane ${ }^{67}$. It exhibits, in vitro, antiproliferative activity against $\mathrm{KB}$ cells. An elegant synthesis of its enantiomer has been planned, starting from copalic acid (2). These efforts have led to the synthesis of the ent-hyrtiosane derivative 163, according to Scheme 17, in 8 steps, with a rather good overall yield of $23 \%{ }^{68,69}$. Hence, methyl isocopalate (6), obtained from copalic acid
(2) in the usual way (see Scheme 1), was transformed into the corresponding aldehyde (159) which was submitted to a Grignard reaction giving a 2:1 mixture of two sesterterpene alcohols (160) epimers at the carbinol carbon. PCC oxidation of this mixture and subsequent epoxidation of the trisubstituted double bond furnished intermediate $\mathbf{1 6 2}$ that could readily be rearranged into hyrtiosane 163 on treatment with boron trifluoride etherate. The overall yield of this synthesis is not available. Subsequently, the enantiomer of a possible biosynthetic precursor of hyrtiosal,<smiles>NC(=O)N1CCCC1</smiles>

178<smiles>O=CC(Cl)Cl</smiles>

179

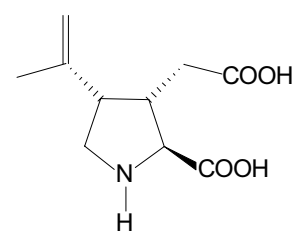

$177 \alpha$-kainic acid

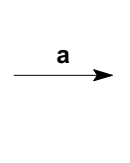

$\mathrm{CBz}$

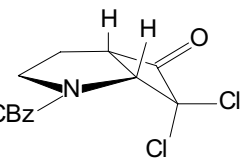

180
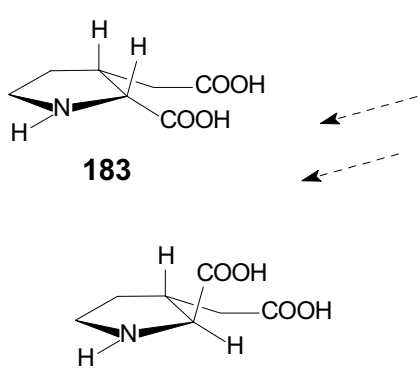

184

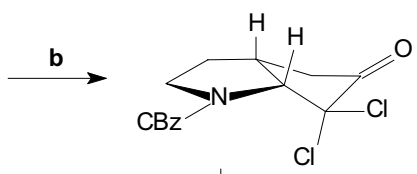

181

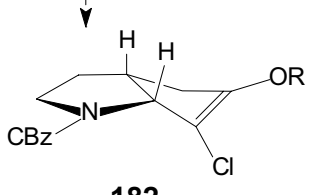

182

Scheme 19. Towards the synthesis of kainic acid analogues.

a. hexane, r.t., $(90 \%)$; b. $\mathrm{CH}_{2} \mathrm{~N}_{2}, \mathrm{MeOH}_{2} \mathrm{Et}_{2} \mathrm{O}(\sim 30 \%)$.

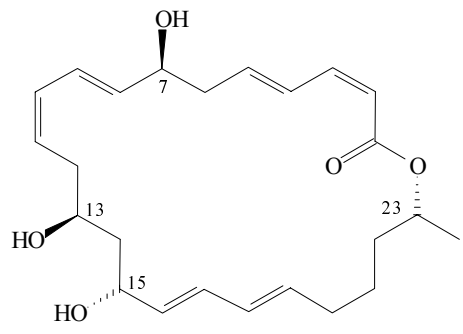

185 macrolactin A

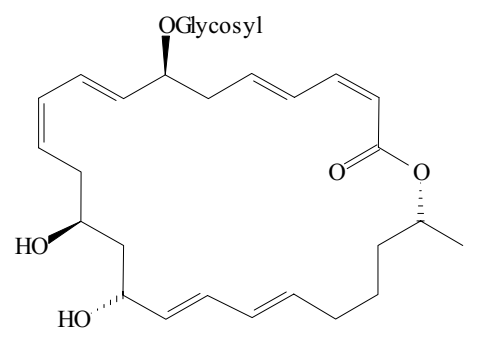

186 macrolactin A

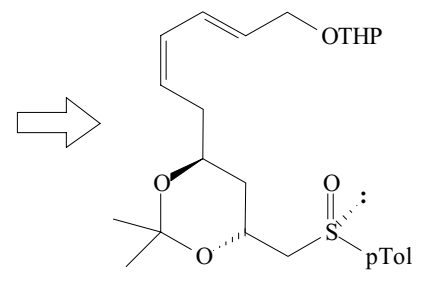

187

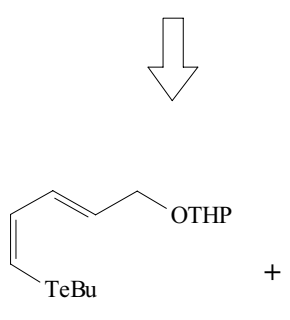

191

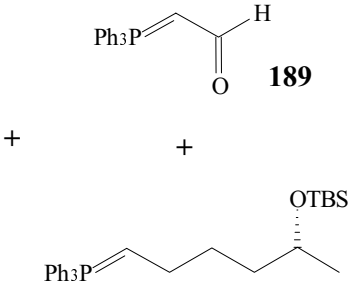

188

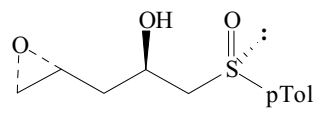

190

Scheme 20. Towards the total synthesis of macrolactin-A. 
furane 156, has been obtained from copalic acid (2) in seven steps (Scheme 17) by extention of the side chain of alcohol 153 and addition of a furane moiety that proceeds in good yield $(62 \%)$. However, this latter step lacks stereoselectivity giving rise to a mixture of $\mathbf{1 5 6}$ and 157, epimers at the carbinol carbon. A sequence of oxidation/reduction has been used to increase the yield of the desired intermediate $\mathbf{1 5 6}^{70,71}$. It may be anticipated that ent-hyrtiosal (152) will now be prepared from 156, in two steps, through intermediate 164.

(-)-Pulo'upone (165) is a minor metabolite isolated in $0.008 \%$ yield from the Hawaiian opistobranch mollusk Philinopsis speciosa (order Cephalaspidea). It is a highly uncommon pyridine derivative substituted at C-2 by a bicyclic polyketide derived $\mathrm{C}_{16}$-alkadienone and has no close analogue among natural or synthetic products ${ }^{72}$. This has made $\mathbf{1 6 5}$ an interesting target for organic synthesis and racemic pulo'upone has already been obtained ${ }^{73}$. Subsequently, the absolute configuration of(-)-pulo'upone was determined by asymmetric total synthesis of both enantiomers $^{74}$. A new approach to assemble the side chain of pulo'upone has now been described (Scheme 18). 6',9'-bi sepi-pulo'upone (176), a diastereoisomer of 165 was prepared starting from propargyl alcohol (166), 2-picoline and the hydrindene moiety (169) ${ }^{75,76}$. Thus, the (E)-3-bromo1-propen-tributylstannane (168) was prepared using a 2step protocol from propargyl alcohol (166), and coupled with the anion of the sulfone $\mathbf{1 6 9}$ to give the (E)-vinylstannyl sulfone 170, along with $35 \%$ recovered starting substrate 169. Desulfonylation to $\mathbf{1 7 1}$, followed by deprotection of the hydroxyl group and treatment with iodine furnished intermediate $\mathbf{1 7 3}$ that was subsequently homologated in a one-pot Swern-Grignard procedure to a mixture of diastereoisomeric carbinols 174. Treatment of the latter mixture with the cuprate derived from 2-picoline provided 175 as a mixture of 2 epimers, that was finally oxidized to bisepi-pulo'upone 176 in $12 \%$ overall yield from hydrindene $\mathbf{1 6 9}^{\mathbf{7 5}, 76}$.

$\alpha$-Kainic acid (177) is a pyrrolidine amino acid known for a very long time. It was first isolated from the red alga Digenea simplex and is endowed of anthelmintic properties justifying its use in popular medicine for centuries ${ }^{4}$. Kainic acid has more recently been implicated in the processes of learning and memory and has consequently received considerable attention in the area of neurosciences ${ }^{77-81}$. A number of syntheses of $\mathbf{1 7 7}$ have already been published and new approaches are being investigated ${ }^{82-85}$. Preliminary results towards the synthesis of kainic acid analogues have appeared and are described in Scheme $19^{85} \cdot[2+2] \mathrm{Cy}-$ cloaddition of cyclic enecarbamate $\mathbf{1 7 8}$ and dichloroketene 179 furnished the dichloro-aza-cyclobutanone 180 that was transformed into the $\alpha, \alpha$-dichloro-cyclopentanone $\mathbf{1 8 1}$ through a regioselective ring expansion carried out with diazomethane in rather low yields $(\sim 30 \%)^{86}$.

The macrolactins are the first members of a novel class of antiviral and cytotoxic macrolides. They were isolated from an unknown Gram-positive bacterium, isolate C-237, from a deep-sea sediment core ${ }^{87}$. Macrolactin-A (185) showed selective antibacterial activity and inhibited B16F10 murine melanoma cancer cells in vitro. It also showed significant inhibition of mammalian Herpes simplex viruses (types I and II) and protected T-lymphoblast cells against human HIV viral replication ${ }^{87}$. The absolute (7S, $13 \mathrm{~S}, 15 \mathrm{R}, 23 \mathrm{R}$ ) stereochemistry of macrolactin-A has been proposed recently from a ${ }^{13} \mathrm{C}-\mathrm{NMR}$ analysis of macrolactin-B (186) ${ }^{88,89}$. Studies toward the synthesis of macrolactin $A$ have already generated the segments $C_{1}-C_{11}$, $\mathrm{C}_{16}-\mathrm{C}_{24}$ and $\mathrm{C}_{15}-\mathrm{C}_{24}{ }^{90,91}$. Both works used organoiron methodologies. A convergent synthesis combining tellurium and sulfoxide chemistry has been planned in order to

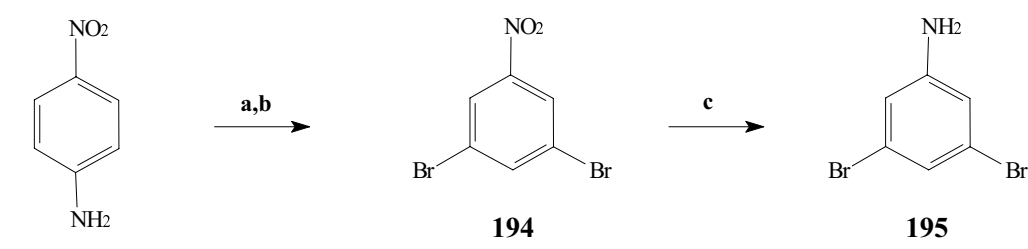

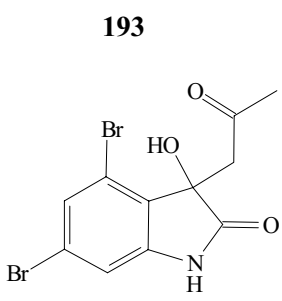

192

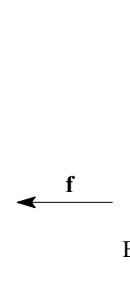

$\mathrm{Br}^{\prime}$

19

197

Scheme 21. Synthesis of convolutamydine A.

a. $\mathrm{Br} 2, \mathrm{AcOH}\left(98 \%\right.$ ); b. $\mathrm{NaNO}_{2}, \mathrm{H}_{2} \mathrm{SO}_{4}, \mathrm{EtOH}$ (97\%); c. (i) $\mathrm{H}_{2}$, Ni-Ra, EtOH,\%); (ii) $\mathrm{HCl}$, EtOH aq. (86-96\%); d. chloral, ( $\mathrm{H}_{2} \mathrm{NOH}_{2} \mathrm{H}_{2} \mathrm{SO} 4, \mathrm{Na}_{2} \mathrm{SO} 4$, $\mathrm{H}_{2} \mathrm{O} / \mathrm{EtOH}(3: 1 \mathrm{v} / \mathrm{v})(82-88 \%) ;$ e. $86 \% \mathrm{H}_{2} \mathrm{SO}_{4}(80-86 \%)$; f. acetone, $\mathrm{Et}_{2} \mathrm{NH}(77 \%)$. 
provide gram quantities of $\mathbf{1 8 5}$ for further biological evaluation. The first step of the retrosynthetic analysis shown in Scheme 20, the coupling of tellurodiene 191 with the hydroxy-epoxide 190, has been achieved in 90\% yield ${ }^{92}$. The final steps of the synthesis are under investigation.

Convolutamydine A (192) is the first dibromohydroxyoxindole alkaloid isolated, from the bryozoan Amathia convoluta $^{93}$, together with a series of bromophenylethylamines and bromophenylethylamides ${ }^{94,95}$. This metabolite exhibits a potent activity in the differentiation of HL-60 human promyelocytic leukemia cells at 12.5 25 $\mu \mathrm{g} / \mathrm{mL}^{93,96}$. A six-step synthesis of racemic 192 has very recently been reported ${ }^{97}$. Thus, bromination of $p$-nitroaniline (193), followed by reductive deamination furnished 3,5-dibromonitrobenzene (194) that was subsequently hydrogenated to 3,5-dibromoaniline (195) using a freshly prepared Raney nickel catalyst. The key-step of the synthesis was the modified Sandmeyer reaction (step d) that delivered the expected isonitrosoacetanilide 196 in 82$88 \%$, an excellent yield when compared to literature data ${ }^{98}$. Acid catalysed cyclization of 196 into 197 and aldol type addition of acetone resulted in the obtention of $( \pm)$-convolutamydine $\mathrm{A}$ in $53 \%$ overall yield [Scheme 21].

\section{Conclusions}

Synthetic studies have focused mainly on terpenes. Among them, 8 sesquiterpenes, 10 diterpenes and one sesterterpene have been the object of total synthesis or of the preparation by transformation of an abundant natural precursor. In addition, the synthesis of one dibromoindole metabolite has been achieved. The syntheses of two nitrogen-containing metabolites and one long-chain lipid are still under investigation.

Target metabolites had been isolated from sponges $(8$ compounds), mollusks (5), octocorals (3), bryozoan (1), red alga (1), bacteria (1) and mammalians (4), and were selected either because of their pharmacological activities (hyrtiosal, $\alpha$-kainic acid, metachromine-A, and macrolactin-A, convolutamydine-A), industrial use (ambergris derivatives) or structure originality (isoagatholactone, brasilenol, africanol, dactylol, pulo'upone).

In most cases, racemic mixtures or the enantiomer of target compounds have been prepared. The syntheses of several of these metabolites had already been published by other groups, with the exception of the four diterpenes from Spongia officinalis, brasilenol, convolutamydine-A, coralloidin-A and metachromine-A. The synthesis of (+)-brasilenol is the only one that not only confirmed structural determination but, in addition, allowed determination of the unknown absolute configuration.

Some syntheses are still underway and have been reported here to present the state of art of what has been (and what is being) done in Brazil in the field of synthesis of marine natural products.

In the third part of this review, we will focus on the biological perspectives of marine natural product research in Brazil. We will describe works on chemosystematics, chemical ecology and marine pharmacology.

\section{Acknowledgements}

The author thanks Professors Sergio Pinheiro and Vitor Francisco Ferreira (both from the Institute of Chemistry, Universidade Federal Fluminense) who furnished some indispensable meeting abstracts, Prof. Carlos Roque Duarte Correia (Institute of Chemistry, UNICAMP) and Prof. Ângelo da Cunha Pinto (Institute of Chemistry, Universidade Federal do Rio de Janeiro) for pre-prints of their works and Artur Maciel (student of pharmacy, Universidade Federal Fluminense) for library work.

\section{References}

1. Grevin, J. Deux Livres des Venins; Christofle Plantin; Anvers, 1568.

2. Bohadtch, cited by Johnston, G. In An introduction to conchology. Or, elements of the natural history of molluscous animals; John Van Voorst; London. 614 p. +102 figs., 1850.

3. Darwin, C.R., cited by Halstead, B.W. In Poisonous and Venomous Marine Animals of the World, vol. I, pp. 1-26; US Government Printing Office; Washington DC, p.710, 1965.

4. Scheuer, P.J. In Chemistry of Marine Natural Products. Academic Press; NY \& London, 1973.

5. Fieser, L.F.; Fieser, M. In Organic Chemistry, 3rd ed., chap. 36 Dyes, p. 908, Reinhold Publ. Corp. New York.

6. Friedländer, P. Ber. Deutsch.Chem. Ges. 1909, 24, 765 [Chem. Abstr. 1909 3, 1268].

7. Friedländer, P.; Schuloff, R. Monatsh. Chem. 1908, 29, 387 and previous papers in this series [Chem. Abstr. 1908, 2, 2680].

8. Pietra, F. Gazz. Chim. Ital. 1985, 115, 443.

9. Kelecom, A. Ciência e Cultura 1997, 49, 321.

10. Yamamura, S.; Terada, Y. Tetrahedron Lett. 1977 25, 2171.

11. Imamura, P.M.; Rúveda, E.A. J. Org. Chem. 1980, 45, 510.

12. Nishizawa, M.; Takenada, H.; Hirotsu, K.; Higuichi, T.; Hayashi, Y. J. Am. Chem. Soc. 1984, 106, 4290.

13. Cimino, G.; De Rosa, D.; De Stefano, S.; Minale, L. Tetrahedron 1974, 30, 645.

14. Imamura, P.M.; Sierra, M.G.; Rúveda, E.A. J. Chem. Soc., Chem. Commun. 1981, 734.

15. Do Klac Manh, D.; Fetizon, M.; Kone, M. Tetrahedron 1975, 31, 1903. 
16. Miranda, D.S. de; Brendolan, G.; Imamura, P.M.; Sierra, M.G.; Marsaioli, A.J.; Rúveda, E.A. J. Org. Chem. 1981, 46, 4851.

17. Nakano, T.; Hernández, M.I. Tetrahedron Lett. 1982, 23, 1423.

18. Cimino, G.; Morrone, R.; Sodano, G. Tetrahedron Lett. 1982, 23, 4139.

19. Mischne, M.P.; Sierra, M.G.; Rúveda, E.A. J. Org. Chem. 1984, 49, 2035.

20. Cimino, G.; De Stefano, S.; Di Luccia, A. Experientia 1979, 35, 1277 and references cited therein.

21. Merck Index 1989, 11 th edition, \# 398, p. 62

22. Escher, S.; Giersch, W.; Niclass, Y.; Bernardinelli, G.; Ohloff, G. Helv. Chim. Acta 1990, 73, 1935.

23. Nunes, F.; Imamura, P.M.; XVI Reunião da Sociedade Brasileira de Química, Caxambu, MG. Química Nova 1993, 16 (Supl), QO-017.

24. Nunes, F.M.N.; Imamura, P.M. VI Brazilian Meeting on Organic Synthesis, São Paulo SP, 1994, p. 59.

25. Nunes, F.M.N.; Imamura, P.M. J. Braz. Chem. Soc. 1996, 7, 181.

26. Walker, R.P.; Faulkner, D.J. J. Org. Chem. 1981, 46, 1098.

27. Walker, R.P.; Rosser, R.M.; Faulkner, D.J. J. Org. Chem. 1984, 49, 5160.

28. Costa, M.; Imamura, P.M. VI Brazilian Meeting on Organic Synthesis, São Paulo SP, 1994, p. 58.

29. Marais, P.C. PhD Thesis Univ. British Columbia, Vancouver, BC, Canada. Diss. Abstr. Int B 1992, 52, 5271.

30. Stallard, M.O.; Fenical, W.; Kittredge, J.S. Tetrahedron 1978, 34, 2077.

31. Greene, A.E.; Coelho, F.; Barreiro, E.L.; Costa, P.P.R. J. Org. Chem. 1986, 51, 4250.

32. Barreiro, E.J.; Coelho, F.A.S.; Costa, P.P.R.; Greene, A.R.; Serra, A.A. Química Nova 1989, 12, 230.

33. Greene, A.E.; Serra, A.A.; Barreiro, E.L.; Costa, P.P.R. J. Org. Chem. 1987, 52, 1169.

34. Tursch, B.; Braekman, J.C.; Daloze, D.; Fritz, P.; Kelecom, A.; Karlsson, R.; Losman, D. Tetrahedron Lett. 1974, 747.

35. Kelecom, A.; Tursch, B.; Braekman, J.C. and Daloze, D. observed a number of rearrangements of the africane skeleton on acid treatment. Thus, when $\mathrm{HCOOH}$ was used, africanol furnished two formates one secondary, the other terciary. These results have never been published.

36. Shirahama, H.; Hayano, K.; Kanemoto, Y.; Misumi, S.; Ohtsuka, T.; Hashiba, N.; Furusaki, A.; Murata, S.; Noyori, R.; Matsumoto, T. Tetrahedron Lett. 1980, $21,4835$.

37. Paquette, L.A.; Ham, W.H. Tetrahedron Lett. 1986, 27, 2341; Paquette, L.A.; Ham, W.H. J. Am. Chem. Soc. 1987, 109, 3025.
38. Sugimura, T.; Futagawa, T.; Tai, A. Chem. Letters 1990, 2295.

39. Weiming, F.; White, J.B. J. Org. Chem. 1993, 58, 3557.

40. Ferreira, J.T.B.; Piers, E.; Marques, F.A. XVI Reunião da Sociedade Brasileira de Química, Caxambu, MG. Química Nova 1993, 16 (Supl), QO-013.

41. Marques, F.A.; Ferreira, J.T.B.; Piers, E. VI Brazilian Meeting on Organic Synthesis, São Paulo SP, 1994, p. 39.

42. Schmitz, F.J.; Hollenbeak, K.H.; Vanderrah, D.J. Tetrahedron 1978, 34, 2719.

43. Hayazaka, K.; Ohtsuka, T.; Shirahama, H.; Matsumoto, T. Tetrahedron Lett. 1985, 26, 873.

44. Paquette, L.; Wang, T.Z.; Vo, N.H. J. Am. Chem. Soc. 1993, 115, 1676.

45. Gadwood, R.C.; Lett, R.M.; Wissinger, J.E. J. Am. Chem. Soc. 1986, 108, 6343.

46. Molander, G.A.; Eastwood, P.R. J. Org. Chem. 1995, $60,4559$.

47. Correia, C.R.D.; Amorim, M.S.; Costa, R.J.M. da. III Brazilian Meeting on Organic Synthesis, São Carlos SP, 1989, p. 105.

48. Lima, E.L.S.; Luiz, V.L.F.; Correia, C.R.D. IV Brazilian Meeting on Organic Synthesis, Teresópolis RJ, 1990, p. 67.

49. Lima, E.L.S.; Correia, C.R.D. J. Braz. Chem. Soc. 1996, submitted.

50. Rivero, R.B.; Perez, A.R.; Castro, H.V; Argilagos, C.S.; Henriquez, R.D. Z. Naturforsch. 1990, 45B, 1571.

51. Costa, M.; Imamura, P.M. XVIII Reunião da Sociedade Brasileira de Química, Caxambu, MG. Química Nova 1995, 18 (Supl), QO-186.

52. Ayer, S.W.; Hellou, J.; Tischler, M.; Andersen, R.J. Tetrahedron Lett. 1984, 25, 141.

53. Araujo, A.R.; Imamura, P.M. IV Brazilian Meeting on Organic Synthesis, Teresópolis RJ, 1990, p. 37.

54. Takahashi, Y.; Kunihiko, T. Chem. Lett. 1993, 29.

55. Guerriero, A.; Dematté, B.; D’Ambrosio, M.; Pietra, F. J. Natl. Prod. 1986, 49, 608.

56. Nogueira, R.T.; Imamura, P.M.; IV Brazilian Meeting on Organic Synthesis, Teresópolis RJ, 1990, p. 38.

57. Imamura, P.M.; Nogueira, R.T. Synth. Commun 1995, $25,405$.

58. Ishibashi, M.; Ohizumi, Y.; Cheng, J.-F.; Nakamura, H.; Hirata, Y.; Sasaki, T.; Kobayashi, J.-I. J. Org. Chem. 1988, 53, 2855.

59. Correia, C.R.D.; Almeida, W.P. XIV Reunião da Sociedade Brasileira de Química, Caxambu, MG. Química Nova 1991, 14 (Supl), QO-177.

60. Almeida, W.P.; Correia, C.R.D. V Brazilian Meeting on Organic Synthesis, Campinas SP, 1992, p. 55. 
61. Almeida, W.P.; Correia, C.R.D. Tetrahedron Lett. 1994, 35, 1367.

62. Faulkner, D.J. Nat. Prod. Rep. 1996, 13, 75 and previous papers in this series.

63. Silva, C.C. da; Almargo, V.; Zukerman-Scheptor, J.; Castellano, E.E.; Marsaioli, A.J. J. Org. Chem. 1994, 59, 2880.

64. Sullivan, B.W.; Faulkner, D.J.; Okamoto, K.T.; Chen, M.H.M.; Clardy, J. J. Org. Chem. 1986, 51, 5134.

65. Gulavita, N.K.; Silva de, E.D.; Hagadone, M.R.; Karuso, P.; Scheuer, P.J.; Van Duyne, G.D.; Clardy, J. J. Org. Chem. 1986, 51, 5136.

66. Marsaioli, A.J.; da Silva, C.C; de Oliveira, C.M. In Organic Synthesis in Brazil: an overview, EDUSP, São Paulo, pp. 1-6, 1994.

67. Iguchi, K.; Shimada, Y.; Yamada, Y. J. Org. Chem. 1992, 57, 522.

68. Carvalho, A.B. de; Imamura, P.M. V Brazilian Meeting on Organic Synthesis, Campinas SP, 1992, p. 60.

69. Carvalho, A.B. de; Imamura, P.M. XVI Reunião da Sociedade Brasileira de Química, Caxambu, MG. Química Nova 1993, 16 (Supl), QO-016.

70. Carvalho, A.B. de; Imamura, P.M. VI Brazilian Meeting on Organic Synthesis, São Paulo SP, 1994, p. 10.

71. Santiago, G.M.P.; Imamura, P.M. VII Brazilian Meeting on Organic Synthesis, Rio de Janeiro RJ, 1996, p. 75.

72. Coval, S.J.; Scheuer, P.J. J. Org. Chem. 1985, 50, 3024

73. Burke, S.D.; Piscopio, A.D.; Buchanan, J.L. Tetrahedron Lett. 1988, 29, 2757.

74. Sugahar, T.; Iwata, T.; Yamaoka, M.; Takano, S. Tetrahedron Lett. 1989, 30, 1821.

75. Simonelli, F.; Ferreira, J.T.B.; Marino, J.P. VII Brazilian Meeting on Organic Synthesis, Rio de Janeiro RJ, 1996, p. 64.

76. Simonelli, F.; Ferreira, J.T.B.; Marino, J.P. J. Braz. Chem. Soc.1996, 7, 231.

77. Berger, M.; Sperk, G.; Hornikiewicz, O. Nature 1982, 299, 254.

78. Peichl, L.; Bolz, J. Science 1984, 223, 503.

79. Akoev, G.N.; Andrianov, G.N.; Szabo, T. Comp. Biochem. Physiol. 1987, 88A, 61.

80. Garthwaite, J.; Garthwaite, G. Nature 1983, 305, 138.
81. Ferkany, J.W.; Zacek, R.; Coyle, J.T. and reply by Garthwaite, J.; Garthwaite, G. Nature 1984, 308, 561.

82. Husinec, S.; Porter, A.E.A.; Roberts, J.S.; Strachan, C.H. J. Chem. Soc. Perlin I 1984, 2517.

83. Cooper, J.; Knight, D.W.; Gallagher, P.T. J. Chem. Soc., Chem. Commun. 1987, 1220.

84. Takano, S.; Iwabuchi, Y.; Ogasawara, K. J. Chem Soc., Chem. Commun. 1988, 1204.

85. Takano, S.; Sugihara, T.; Satoh, S.; Ogasawara, K. J. Am. Chem. Soc. 1988, 110, 6467.

86. del'Rey, R.R.H.; Carpes, M.J.S.; Correia, C.R.D. VI Brazilian Meeting on Organic Synthesis, São Paulo SP, 1994, p. 79 and Tetrahedron Lett. 1997, 38,1869.

87. Gustafson, K.; Roman, M.; Fenical, W. J. Am. Chem. Soc. 1989, 111, 7519.

88. Skalitzky, D.J.; PhD Thesis, Univ. Minnesota, MN, USA. Diss. Abstr. Int B 1993, 53, 5727.

89. Rychnovsky, S.D.; Skalitzky, D.J.; Pathirana, C.; Jensen, P.R.; Fenical, W. J. Am. Chem. Soc. 1992, 114, 671.

90. Benvegnu, T.; Schio, L.; Le Floc'h, Y.; Gree, R. Synlett. 1994, 505.

91. Donaldson, W.A.; Bell, P.T.; Wang, Z.; Bennett, D.W. Tetrahedron Lett. 1994, 35, 5829.

92. Comasseto, J.V.; Tucci, F.C.; Marino, J.P.; Holub, D.P. VI Brazilian Meeting on Organic Synthesis, São Paulo SP, 1994, p. 72.

93. Kamano, Y.; Zhang, H.; Ichihara, Y.; Kizu, H.; Komiyama, K.; Pettit, G.R. Tetrahedron Lett. 1995, 36, 2783.

94. Zhang, H.; Kamano, Y.; Kizu, H.; Itokawa, H.; Pettit, G.R.; Herald, C.L. Chem. Letters 1994, 2271.

95. Zhang, H.; Shigemori, H.; Ishibashi, M.; Kosaka, T.; Pettit, G.R.; Kamano, Y.; Kobayashi, J. Tetrahedron 1994, 50, 10201.

96. Zhang, H.-P.; Kamano, Y.; Ichihara, Y.; Kizu, H.; Komiyama, K.; Itokawa, H.; G.R. Pettit, G.R. Tetrahedron 1995, 51, 5523.

97. Garden, S.J.; Torres, J.C.; Ferreira, A.A.; Silva, R.B.; Pinto, A.C. Tetrahedron Lett. 1997, 38, 1501.

98. Baker, B.R.; Schaub, R.E.; Joseph, J.P.; McEvoy, F.J.; Williams, J.H. J. Org. Chem. 1952, 17, 149. 